IZA DP No. 5523

Overeducation and Mismatch in the Labor Market

Edwin Leuven

Hessel Oosterbeek

February 2011 


\title{
Overeducation and Mismatch in the Labor Market
}

\author{
Edwin Leuven \\ CREST (ENSAE), \\ CEPR, CESifo and IZA \\ Hessel Oosterbeek \\ University of Amsterdam, \\ Tinbergen Institute and TIER
}

\section{Discussion Paper No. 5523 \\ February 2011}

\author{
IZA \\ P.O. Box 7240 \\ 53072 Bonn \\ Germany \\ Phone: +49-228-3894-0 \\ Fax: +49-228-3894-180 \\ E-mail: iza@iza.org
}

\begin{abstract}
Any opinions expressed here are those of the author(s) and not those of IZA. Research published in this series may include views on policy, but the institute itself takes no institutional policy positions.

The Institute for the Study of Labor (IZA) in Bonn is a local and virtual international research center and a place of communication between science, politics and business. IZA is an independent nonprofit organization supported by Deutsche Post Foundation. The center is associated with the University of Bonn and offers a stimulating research environment through its international network, workshops and conferences, data service, project support, research visits and doctoral program. IZA engages in (i) original and internationally competitive research in all fields of labor economics, (ii) development of policy concepts, and (iii) dissemination of research results and concepts to the interested public.
\end{abstract}

IZA Discussion Papers often represent preliminary work and are circulated to encourage discussion. Citation of such a paper should account for its provisional character. A revised version may be available directly from the author. 
IZA Discussion Paper No. 5523

February 2011

\section{ABSTRACT}

\section{Overeducation and Mismatch in the Labor Market ${ }^{*}$}

This paper surveys the economics literature on overeducation. The original motivation to study this topic were reports that the strong increase in the number of college graduates in the early 1970s in the US led to a decrease in the returns to college education. We argue that Duncan and Hoffman's augmented wage equation - the workhorse model in the overeducation literature - in which wages are regressed on years of overschooling, years of required schooling and years of underschooling is at best loosely related to this original motivation. We discuss measurement and estimation issues and give an overview of the main empirical findings in this literature. Finally we given an appraisal of the economic lessons learned.

JEL Classification: $\quad 12$

Keywords: mismatch, overschooling, underschooling, wage equation

Corresponding author:

Edwin Leuven

ENSAE

3, avenue Pierre Larousse

92245 Malakoff Cedex

France

E-mail: edwin.leuven@ensae.fr

\footnotetext{
* This paper has been prepared for the Handbook of the Economics of Education. We gratefully acknowledge valuable comments from the editors Eric Hanushek, Stephen Machin and Ludger Woessmann and the participants of a Handbook conference in Munich.
} 


\section{Contents}

1 Introduction 2

2 Questions 5

3 Measurement issues $\quad 9$

3.1 Job requirements . . . . . . . . . . . . . . . . . . . 9

3.2 Overskilled . . . . . . . . . . . . . . . . . . . . 13

4 Incidence $\quad 15$

4.1 Aggregate incidence . . . . . . . . . . . . . . . . . . 15

4.2 Individual level - determinants . . . . . . . . . . . . . . . . . 17

4.3 Individual level - dynamics . . . . . . . . . . . . . . . . . . . . . . . 19

5 Impact on earnings $\quad 22$

5.1 Omitted variable bias . . . . . . . . . . . . . . . . . . 24

5.2 Measurement error . . . . . . . . . . . . . . . . 26

5.3 Findings . . . . . . . . . . . . . . . . . . . 30

6 Relation to labor market theories $\quad 32$

6.1 Human capital . . . . . . . . . . . . . . . . . . . . . . . . 32

6.2 Career mobility . . . . . . . . . . . . . . . . . . . . . . 34

6.3 Job competition . . . . . . . . . . . . . . . . 35

6.4 Signaling/screening . . . . . . . . . . . . . . . . . 36

6.5 Preferences . . . . . . . . . . . . . . . 36

6.6 Search and frictions . . . . . . . . . . . . . . . . 37

$\begin{array}{lll}7 & \text { Conclusion } & 37\end{array}$

$\begin{array}{ll}\text { A Overview of over/underschooling studies } & 47\end{array}$ 


\section{Introduction}

Pointing to an analogy between countries' agricultural methods and their perspectives towards education, Gladwell (2008) describes the views of early educational reformers in the United States on overeducation. He refers to the historian Gould who points out that these reformers were very concerned that children got too much education. To illustrate this, Gould cites the US commissioner of education Jarvis who in 1872 published a report under the title "Relation of Education to Insanity" in which he claims that of the 1,741 cases of insanity he studied, "over-study" was responsible for 205 of them. "Education lays the foundation of a large portion of the causes of mental disorder". Gladwell also quotes Mann - a pioneer of public education in Massachusetts - who believed that "not infrequently is health itself destroyed by over-stimulating the mind". ${ }^{1}$

More recently, concerns with overeducation were expressed in the 1970s when the supply of educated workers seemed to outpace its demand in the labor market (Berg, 1970; Freeman, 1975, 1976), apparently resulting in a substantial reduction in the returns to schooling. This is illustrated in Figure 1, which is based on data presented in Smith and Welch (1978). The numbers from 1969 to 1974 (between the vertical lines) in panel A reproduce the key evidence provided by Freeman (1976). The line "New entrants" shows a sharp decline in the ratio of the average income of new entrants with a college degree and the average income of high school graduates of the same age (between 25 and 34). In a period of just six years the income premium fell from 40 percent to 16 percent. This decline suggests that supply outpaced demand and caused concerns about overinvestment in college education in the US. In his book "The Overeducated American", which was published in 1976, Freeman predicts that a situation with substantial oversupply of college graduates is likely to remain for many years to come. Due to this prediction the book attracted much attention.

Soon after its publication, Freeman's book was critically reviewed by Smith and Welch (1978). ${ }^{2}$ They first added data for two years prior to the period covered in Freeman's analysis and for two years following his period (the dashed line segments in Figure 1). Adding this information clearly tunes down the spectacular gist of the

\footnotetext{
${ }^{1}$ Gladwell argues that such concerns were totally absent in East-Asian countries like Japan, Singapore and Korea. He points to the analogy between this difference in perspectives on schooling and the difference in agricultural methods in both parts of the world. Growing rice is much more labor intensive than growing wheat, and moreover, the quality of rice paddies improves after every crop (even with multiple crops per year). In contrast wheat fields need to be idle once every so many seasons.

${ }^{2}$ There were many other critical reviews, including Hammack (1978) and Levin (1977).
} 


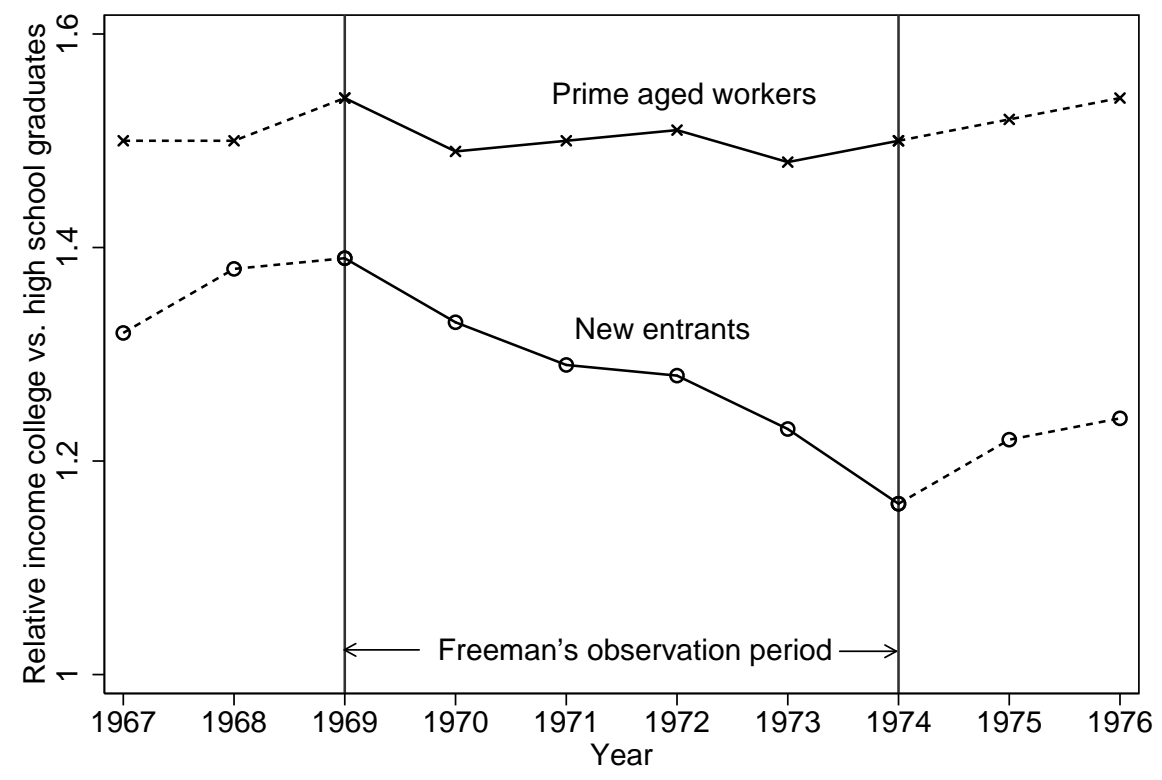

Data Source: Smith and Welch (1978), Table 1 p.6

(a) Relative to high school graduates of the same age

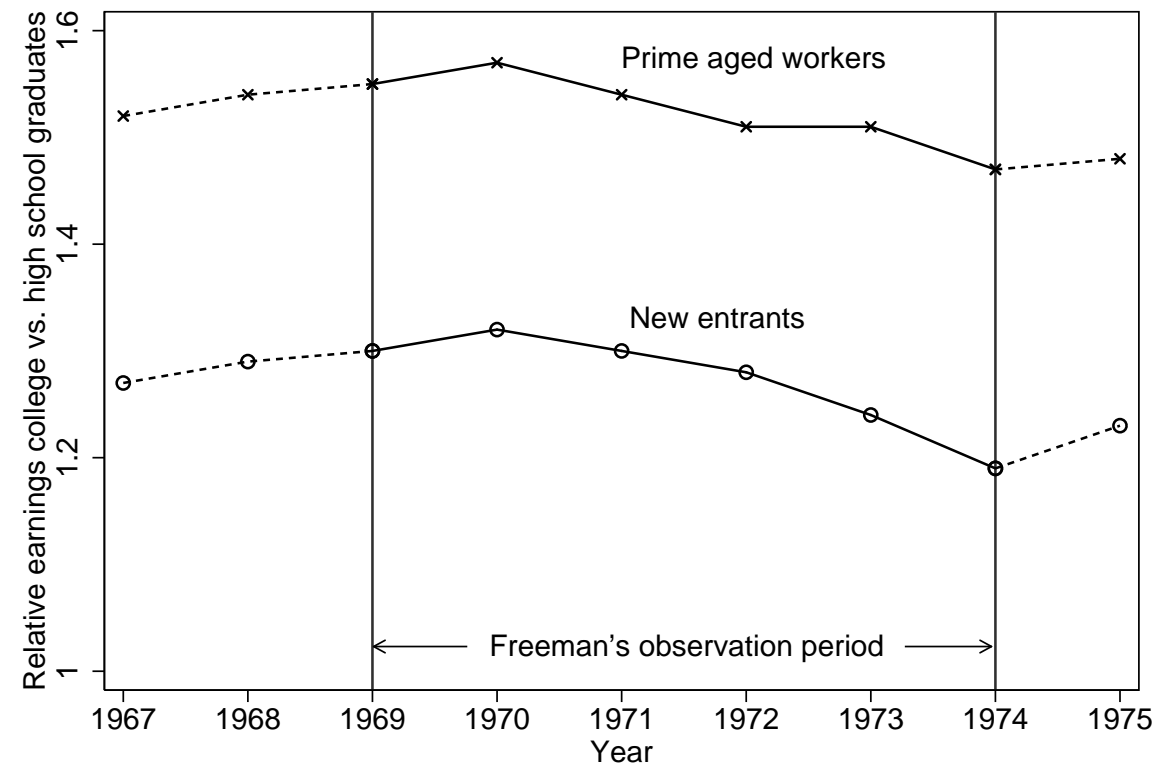

Data Source: Smith and Welch (1978), Table 5 p.32

(b) Relative to high school graduates entering the labor market at the same time

Figure 1. Ratio of income/earnings of college to high school graduates 
graph: between 1967 and 1976 the fall in the income ratio among new entrants is only 8 percentage points instead of 24 .

Smith and Welch argued that the evidence is more consistent with an overcrowded labor market amongst new entrants due to larger cohort sizes than with a situation of overeducation. The line for "New entrants" in panel A compares earnings of college graduates in the age bracket of 25-34 with the earnings of high school graduates in that same age bracket. But while college graduates enter the labor market around age 25, high school graduates enter the labor market at an earlier age. Hence, the graph compares earnings of new entrants with college to earnings of high school graduates with some years of labor market experience. This means that although the line suggests that the college premium for new entrants has declined, it may as well be explained by new entrants from large cohorts (college graduates of 25-34 in 1973 and 1974) being in a disadvantaged position relative to those with some experience from large cohorts (high school graduates of 25-34 in 1973 and 1974). To eliminate the effect of labor market experience, Smith and Welch compare the earnings of college graduates in the age bracket of 25-34 to the earnings of high school graduates of 20-29. This gives the "New entrants" line of panel B. Although the ratio still reaches its lowest value in 1974, the declining trend observed here is much less pronounced. ${ }^{3}$

Although Smith and Welch's review together with the increase in relative earnings of college graduates shortly after 1974 seem sufficient reasons to temper concern about overeducation, the overeducation literature was revitalized by the publication of Duncan and Hoffman's paper "The Incidence and Wage Effects of Overeducation" in 1981 in the first issue of the Economics of Education Review. ${ }^{4}$ Duncan and Hoffman followed the lead of Eckaus (1964) and Berg (1970) to analyze overeducation by confronting levels of education supplied by workers and education levels "demanded" by jobs. But where previous authors confronted these two variables at an aggregate level, Duncan and Hoffman analyze overeducation at an individual level by comparing workers who end up in a job that matches their level of acquired education to workers that end up in a job that requires more education or less schooling than

\footnotetext{
${ }^{3}$ Later studies about wage inequality across skill groups confirm that the drop in the college premium observed by Freeman was a short-lived phenomenon (see Autor and Katz, 1999).

${ }^{4}$ The top journals (American Economic Review, Journal of Political Economy, Quarterly Journal of Economics, Econometrica and the Review of Economic Studies) published hardly anything on the topic. To a large extent this is also true for the top field journals (Journal of Labor Economics, Journal of Human Resources, Review of Economics and Statistics and the Industrial and Labor Relations Review). In contrast five papers in the top-10 of most cited papers published in the Economics of Education Review have overeducation as their topic. These are: Hartog (2000)(rank 1; 95 citations), Duncan and Hoffman (1981)(4; 78), Groot and Maassen van den Brink (2000)(5; 68), Dolton and Vignoles (2000) (6; 62), Hartog and Oosterbeek (1988)(9; 55).
} 
they acquired. They introduced a specification of the wage equation that allows for the separate estimation of returns for years of education required for the job, years of overeducation and years of undereducation:

$$
\ln w_{i}=\delta_{r} S_{i}^{r}+\delta_{o} S_{i}^{o}+\delta_{u} S_{i}^{u}+x_{i}^{\prime} \beta+\varepsilon_{i}
$$

where $w_{i}$ denotes the wage, $S^{r}$ is years of education required for the job, $S^{o}$ years of overeducation, and $S^{u}$ years of undereducation. $x_{i}$ is a vector of control variables including experience and experience squared. $\delta_{r}, \delta_{o}$ and $\delta_{u}$ are the returns to required years of education, years of overeducation and years of undereducation, respectively.

Duncan and Hoffman's seminal paper triggered the start of a separate sub-field: the economics of overeducation. ${ }^{5}$ This chapter reviews this literature. ${ }^{6}$ The next section analyzes how the approach of Duncan and Hoffman relates to the original overeducation literature, and which questions their approach potentially addresses.

In Section 3, we describe how different authors have measured required education, and thereby overeducation and undereducation. We then turn in Section 4 to the incidence of overeducation and undereducation and to the factors that correlate with overeducation and undereducation. In Section 5 we turn to a more detailed discussion of Duncan and Hoffman's wage equation. This section discusses the specification of the wage equation, it gives an overview of the results that have been obtained using this specification, and it discusses problems with this approach due to omitted variable bias and measurement error issues. In Section 6 we discuss how the findings relate to different theories about the functioning of the labor market. These theories include human capital theory, career mobility, job competition theory, signaling/screening, preferences, and search and matching. The final section summarizes and concludes.

\section{Questions}

The question whether there is overinvestment in education is interesting and clearly relevant from a policy perspective. Especially in the context of continental European countries where education is heavily subsidized, it is important to know whether education investments pay off. In Freeman's framework, the key indicator

\footnotetext{
${ }^{5}$ We asked Professor Duncan how he perceives the continued success of their specification. He responded that "It took awhile for the simplicity of the required, surplus and deficit categorization to dawn on us, but I think that its transparency led people to remember the results and the analysis. Also, the topic sits in the middle of the human capital, credentialing and labor market institutions literatures, a popular place to be."

${ }^{6}$ Other reviews of this literature include: Groot and Maassen van den Brink (2000); Hartog (2000); McGuinness (2006); Sloane (2003).
} 
for overinvestment in education is the rate of return to education, or the college premium.

Freeman's analysis fits the neoclassical framework. The college wage premium falls in response to an increase in the supply of highly educated workers. This can happen because firms adjust their production technology to take advantage of the now relatively cheaper and abundant input factor of highly educated workers. It can also happen through a process in which highly educated workers compete for a limited number of skilled jobs by underbidding the wages they demand. Whether firms adjusted their technology can be inferred from changes in the required levels of skills.

In theory, both private and social returns to education investments can be calculated, where the latter takes government expenditures and externalities into account. Estimation and valuation of externalities is, however, difficult. If the return (preferably the social) is low in comparison to returns on investments that are equally risky, this can be regarded as evidence of overinvestment. It is important to realize that this is indicative for overinvestment at an aggregate level. From a policy perspective, this is also the relevant level; overinvestment at the aggregate level can be addressed by reducing public subsidies to education or (in extreme cases) limiting access to education institutes.

The overeducation literature that emerged in the footsteps of Duncan and Hoffman's seminal contribution has been mainly occupied:

- with the incidence of overeducation and its determinants at the individual level, and

- with estimating Duncan and Hoffman's extended wage equation in order to obtain separate estimates of returns to required education, overeducation and undereducation.

While Duncan and Hoffman's approach is more detailed and precise than Freeman's macro approach, and can therefore not be less informative, it turns out that the additional information it provides has sometimes led to - in our view - misleading inferences.

Duncan and Hoffman's analysis of overeducation at the individual level reflects a different view on the functioning of labor markets. They argue that overeducation can only be a serious, long-run problem, if changes in the relative supplies of different types of education have little or no effect on the skill composition of labor demand, implying production technologies with fixed skill requirements. Production is not redesigned, jobs are not upgraded, and some workers end up in a job below their 
skill level. In this view, Duncan and Hoffman argue, jobs are characterized by fixed productivity levels and fixed wages, and individuals working below their skill level, produce and earn the same as workers with less schooling in the same job. When they introduce their specification of the wage equation, Duncan and Hoffman claim that it offers "[a] straightforward way to examine the economic effects of over- (and under-) education".

Obviously, from the shares of overeducated, undereducated and adequately educated workers together with the returns to required education, overeducation and undereducation, it is possible to recover the return to actually attained schooling which is the statistic on which Freeman would base his diagnosis of overschooling. To see how the additional information is interpreted, it is instructive to quote the conclusions from some papers that estimated Duncan and Hoffman's wage equation.

"[W]ages do not appear to be determined solely on the basis of educational requirements. ... surplus education has a positive and significant effect on wage rates ... [I]t clearly does matter, in analyzing the effects of education on earnings, whether any additional year of education is required or surplus ... [T] $[$ he estimated coefficient on years of surplus education is approximately half as large as the coefficient on required years of education ..." and this "suggests some potential misallocation of educational resources." (Duncan and Hoffman, 1981)

"This means that workers who are working in occupations that demand less schooling than they actually have (overeducated) get higher wages than their coworkers (holding other characteristics constant) but lower wages than workers with similar levels of schooling who work in jobs in which their schooling equals what is required." (Sicherman, 1991)

"This suggests that additional schooling is not completely unproductive, but simply that jobs constrain the ability of workers to fully utilize the skills and capabilities they acquire in school." (Rumberger (1987), p.46) "Being overeducated lowers an individuals expected earnings, but the schooling that causes an individual to become overeducated generally results in a wage increase." (Rubb (2003b), p.70)

" $[\mathrm{O}]$ vereducation incurs significant wage costs on the individual and productivity costs on the economy that may well rise if higher education participation continues to expand without a corresponding increase in the number of graduate jobs." (McGuinness (2007), p.147)

"More importantly, the returns to surplus and deficit schooling are very 
low in absolute value and represent only around $45 \%$ of the returns to required schooling. Thus, both the human capital model - which would predict equal returns to adequate, over- and under-education - and the job competition model - that would predict zero returns to surplus and deficit years - can be rejected." (Slonimczyk, 2008)

"In all cases, those with surplus education received a wage premium and those with deficit education suffered a wage penalty. These findings support the idea that productivity on any job is affected by the level of education a worker brings to employment." (Daly et al., 2000)

And, finally,

"In regard to the wage effects of over- and underschooling, we find that the rate of return to overschooling is positive but lower than the rate of return to adequate schooling, and that the rate of return to underschooling is negative. Also, in general, overschooled (underschooled) workers have wages that are substantially lower (higher) than the wages they would have earned in a job for which they are adequately schooled. In addition, we found that the rates of return to adequate schooling and overschooling (underschooling) decline (rise) as labor market experience rises". (Cohn and Ng (2000), p.166)

All quotes focus on the fact that different components of schooling earn different rewards - and almost all quotes phrase this finding as a causal effect. According to the same quotes, this is considered to be interesting from the perspective of different theories about wage setting. The quotes also suggest that these separate estimates are interesting for their own sake. It is unclear, however, why this is the case. Some quotes suggest that overschooling could (or should) be avoided by reducing the amount of schooling. Given a sufficiently high average return to attained schooling, this is only useful if it is known in advance who will end up being overeducated and who will end up in a job that matches the actual schooling level. Other quotes suggest that overschooled workers should be assigned to more demanding jobs. It is left unspecified who will create these more demanding jobs and who gets them.

Alternatively, separate estimates for the three education components are of interest if we want to estimate the efficiency gain from overeducated workers and undereducated workers swapping jobs. This approach expresses that the current allocation of workers to jobs contains mismatches. How many job swaps are possible depends on the levels of attained and required education of the mismatched workers. While it is unlikely that such job swaps will come about on a voluntary basis 
(because undereducated workers are likely to loose from it), estimates of returns to undereducation, overeducation and required education will allow us to compute the potential aggregate wage gain from such a reallocation. This requires, however, that these estimates can be interpreted as the causal effects of moving a person with a given level of education from one job level to another job level. The review in the next sections, argues that this is typically not the interpretation that can be given to the estimates from the overeducation literature.

\section{$3 \quad$ Measurement issues}

Before being able to address the questions of the previous section, one first needs to solve a measurement issue, namely how to define over and undereducation. In the literature this is typically done by comparing individuals' education to educational requirement of job or occupations. In the next subsection we describe the various ways in which required schooling has been measured. Subsection 3.2 introduces the related concept of "overskilled" and how people have measured this.

\subsection{Job requirements}

Overschooling is usually defined as the difference between a worker's attained or completed level of schooling and the level of schooling required for the job the worker holds. To measure overschooling, most studies therefore start by measuring the required level of schooling. Required schooling has been measured in three different ways. The first method asks workers about the schooling requirements for their job. The second method is based on information that is included in job descriptions. The third method uses information from realized matches. Below we discuss these methods in some more detail. This description is important for later uses (especially Section 5) when we discuss measurement error issues.

Self-assessment Measures based on workers' self-assessment rely on questions that ask workers about the schooling requirements of their job. While this may sound straightforward, it turns out that the exact phrasing varies substantially across studies. Some examples help to illustrate this point.

1. How much formal education is required to get a job like yours? (Duncan and Hoffman, 1981)

2. If someone was applying nowadays for the job you do now, would they need any education or vocational schooling beyond compulsory education? And if so, 
about how many years of education or vocational schooling beyond compulsory education would they need? Galasi $(2008)^{7}$

3. Which education, according to you, is the best preparation for the work you are doing? (Hartog and Oosterbeek, 1988)

4. What kind of education does a person need in order to perform in your job? (Alba-Ramirez, 1993)

The first two questions refer to recruitment standards, while the last two refer to requirements to perform in the job. But the first and the second question also differ, with the first only referring to formal education and the second explicitly referring to informal schooling. And also the third and fourth question differ in an important dimension, with the third asking for the best preparation and the fourth asking what is needed to perform. It is quite conceivable that the same person gives four different answers to all four questions. Evidence of this is reported by Green et al. (1999). They asked alumni from the University of Newcastle how much schooling is required to get their current job and how much schooling is required to do their job. A quarter of their respondents give different answers to these two questions. Moreover, moving from one question to the other may also affect the ordering of answers. The more fundamental problem is that questions differ in the factors respondents are supposed to condition their answers on. It is not clear whether and to what extent differences in framing and phrasing causes differences in the measured levels of required schooling.

Workers' self-assessment of the required amount of schooling of their job is by definition subjective. According to Hartog (2000) respondents may have a tendency to overstate the requirements of their jobs, to upgrade the status of their position. This tendency may differ between persons doing the same job, and may even systematically differ with attributes that have an impact on wages, such as gender or completed years of schooling.

A potential advantage of self-assessment is that it is in principle based on all the relevant information. The downside is, however, that workers may be very poorly informed about the relevant counterfactuals; how can they be informed about the performance in the same job of people with different levels of completed schooling?

\footnotetext{
${ }^{7}$ Using these questions, Galasi (2008) reports fractions of over- and underschooling that are far off the fractions normally reported in the literature. In a sample of workers from 25 countries, he finds $33 \%$ of overschooled workers (with a low $15 \%$ in the Netherlands and a high $67 \%$ in Ireland) and $59 \%$ of underschooled workers (with a low $13 \%$ in Estonia and a high $82 \%$ in the Netherlands). Only $8 \%$ is properly educated (with a low $1 \%$ in Turkey and a high $19 \%$ in Austria).
} 
A variation of workers' self-assessment of the schooling requirements of their jobs is to ask them directly whether they are overschooled, underschooled or rightly educated for their job (cf Chevalier, 2003 and Verhaest and Omey, 2006b).

Job analysis A second approach to measure required schooling levels is based on information contained in occupational classifications. A well-known example is the Dictionary of Occupational Titles which contains an indicator for educational requirements in the form of the General Educational Development (GED) scale. This scale runs from 1 to 7 . These GED categories are then translated into school years equivalents (0 to 18) (cf. Eckaus, 1964, p.184).

Measures based on job analyses are attractive because they are based on the technology of the job. As disadvantages, Hartog (2000) mentions that updates are infrequent and sometimes not so accurate because they are costly. Other disadvantages have been identified by Halaby (1994) specifically pertaining to the use of the GED. He argues that there is no consensus on the conversion of the GED scale to years of schooling. Secondly, the procedure assumes that there is a fixed required schooling level within an occupation rather than a distribution of required schooling across jobs. For a large number of occupations (47\%), it was found that 1960 median schooling was less than the GED requirement, and finally - according to some - the GED scores merely measure social standing of an occupation instead of schooling requirements. All in all, the reliability and the validity of the measure based on job analysis have been called into question (cf. Hartog, 2000, p. 132).

Realized matches The third method uses information from realized matches (Verdugo and Verdugo, 1989). ${ }^{8}$ In this method the required amount of schooling for a worker is inferred from the mean of completed schooling of all workers holding the same occupation. Verdugo and Verdugo defined occupations at the three digit code, and most others applying this method followed that example. People are then defined to be overschooled or underschooled if their completed level of schooling deviates at least one standard deviation from the mean in their occupation.

Kiker et al. (1997) proposed a method that is closely related; they define the required schooling level in a job as the mode of the completed schooling levels of the people working in that job. People that have more or less than this amount are over/undereducated. Note that this measure does not use the two standard deviations interval around the centrality measure.

The use of realized matches is often regarded as inferior to the other two methods

\footnotetext{
${ }^{8}$ This method goes back to Sullivan (1978) and Clogg (1979).
} 
and is only used if the data do not contain one of the other measures. The main reason for this is that the realized match is the result of demand and supply forces, and does not only reflect requirements. ${ }^{9}$ Moreover, - like the method based on job analysis - it ignores variation in required schooling across jobs within an occupation. Furthermore, the cutoff at one standard deviation from the mean is arbitrary.

Another variation of this method was proposed by Quinn and Rubb (2006), who argue that required education may be dynamic due to changes in technology and educational quality. They therefore allow required education to vary with year of birth and survey year. In practice required education for a given occupation is then equal to the coefficient on the relevant occupation dummy from a regression of actual education on occupation dummies, birth year and survey year (omitting a constant term).

Groeneveld and Hartog (2004) use the indication used in hiring by the personnel department of the organization as measure of required schooling. They argue that it seems fair to assume that the personnel department has good information on technically required qualifications for a particular job. This measure combines elements of each of the other three measures. It is close to the worker and subjective (as in workers' assessments), it uses insights from personnel experts (as in the job analysis method), and also reflects current market forces (captured by the reference to hiring standards).

Gottschalk and Hansen (2003) argue that the lack of attention in the economics literature to the possibility that college workers were displaced into jobs formerly held by noncollege workers, is due to the subjective nature of classifications of occupations as college jobs and noncollege jobs. They give workers' self-assessment and job analysis as examples of this type of classification. As an alternative they propose to define a noncollege job as a job that offers a low college premium. An occupation with a large college premium signals that college workers have skills that are valued by employers in that occupation (p. 455). This approach to measure skill requirement is conceptually closed to Verdugo and Verdugo's approach as their classification is also based on market signals (i.e., employers' willingness to pay a premium for college-educated workers) rather than on subjective judgments. At the same time these two approach may produce very different results.

Gottschalk and Hansen (2003) estimate occupation-specific log wage regressions to obtain occupation-specific college premiums. Occupations with a college premium below a certain threshold are classified as noncollege jobs. Using a threshold

\footnotetext{
${ }^{9}$ Notice, however, that the same argument applies to methods using information based on hiring standards (such as the question used in Duncan and Hoffman, 1981).
} 
of 10 percent, they find that in $1983,10.7 \%$ of all college graduates worked in a noncollege job. ${ }^{10}$ They also show that their approach gives a rather different picture of the development of the share of college graduates in a noncollege job than would be obtained if workers' self-assessment is used. While their approach shows a 6.6 percentage points decline in this share between 1983 and 1994, based on workers' self-assessment there is a 2.2 percentage points increase.

\subsection{Overskilled}

At one point, various authors became concerned with the fact that overschooled workers need not be identical to adequately matched workers. Overschooled workers may have lower skill levels and overschooling does therefore not necessarily imply that someone is overskilled (e.g. Allen and Van der Velden 2001).

One approach to correct for such unobserved heterogeneity or omitted variable bias, is an instrumental variable approach that exploits exogenous variation in the levels of completed schooling and required schooling. ${ }^{11}$ So far finding credible instrumental variables has proven to be very difficult (if not impossible), and researchers have instead constructed measures that somehow attempt to capture workers' excess skill. An example is Chevalier (2003) who criticized the (then) existing measures of overschooling because they implicitly assume that all workers with a given education level are perfect substitutes.

For the case of university graduates, Chevalier distinguishes two ability levels (clever and under-achiever) and three job levels (graduate jobs, non-graduate jobs, and upgraded non-graduate jobs). The following allocations are possible in this setup: clever workers can end up in a graduate job or in an upgraded job. In a graduate job their match is perfect, in an upgraded job they are genuinely overeducated. Underachievers can end up in an upgraded job of in a non-graduate job. In an upgraded job they are apparently overeducated, in a non-graduate job they are genuinely overeducated. ${ }^{12}$

\begin{tabular}{lcc}
\hline & Clever & Underachiever \\
\hline Graduate job & Perfect match & $\mathrm{X}$ \\
Upgraded non-graduate job & Genuine overeducation & Apparent overeducation \\
Normal non-graduate job & $\mathrm{X}$ & Genuine overeducation \\
\hline
\end{tabular}

\footnotetext{
${ }^{10}$ At the same time, the correlation between the occupation-specific college premium and the wages offered to college graduates within an occupation is positive but weak (0.33).

${ }^{11}$ In Section 5 we show that exogenous variation in just one of these is not enough to identify the return to overschooling.

${ }^{12}$ By assumption clever graduates cannot end up in a normal non-graduate job, and underachievers cannot end up in a graduate job.
} 
Neither the worker's skill level nor whether a non-graduate job has been upgraded are observed in his data. Instead Chevalier uses information about workers' satisfaction with the match between their work and their qualifications. Graduates who work in a non-graduate job are considered genuinely overschooled if they are dissatisfied with this match, otherwise they are considered to be apparently overschooled. Using a sample of almost 5,000 individuals who graduated from a higher education institution in the United Kingdom in 1985 or 1990, he finds that $10 \%$ of these individuals is apparently overschooled and $6 \%$ is genuinely overschooled. From the fact that apparently overschooled workers believe much more than the genuinely overschooled that their degree contributed in getting an interesting job, Chevalier infers that most of the genuinely overschooled are underachievers in non-graduate jobs (the bottom right cell) instead of clever graduates in upgraded jobs (the middle left cell). Further support for this is that within the overschooled group, the apparently overschooled have better credentials than the genuinely overschooled. In a follow-up paper, Chevalier and Lindley (2009) find evidence that the genuinely overschooled lack graduate skills such as management and leadership skills.

Chevalier argues that genuinely overschooled people may move to a higher level job over time, while apparently overschooled workers are unlikely to do so. This is consistent with the observation that a substantial fraction of overschooled workers are permanently in this status.

Motivated by similar concerns as Chevalier, Green and McIntosh (2007) make the distinction between overqualified and overskilled. Someone is defined to be overskilled if $\mathrm{s} /$ he disagrees with the statement that the current job offers the opportunity to use the knowledge and skills s/he has, or when the respondent indicated to make little use of past experience, skill and abilities in the present job. The authors report that the correlation between being overqualified and being overskilled is of moderate strength (0.2). Less than half of the employees who are overqualified report to have skills and abilities they are not using in their job. At the same time $28 \%$ of those who are not overqualified report that they underutilise their skills.

The information that Chevalier, and Green and McIntosh use is admittedly based on subjective self-assessments that probably contain a substantial amount of measurement error. Yet, their results give a strong indication that the estimated return to overschooling in Duncan and Hoffman's wage equation is biased. ${ }^{13}$

We have seen that the existing approaches to measuring overschooling are very

\footnotetext{
${ }^{13}$ Overskilling is not the only new concept introduced in the overschooling literature. In fact there is a whole range of closely related terms that researchers working on overschooling issues use. In a report on skill mismatch in Europe, CEDEFOP (2010) even introduces a glossary of - mostly self-explanatory - terms.
} 
much data driven. Ideally one would like to have a theoretical basis for measurement and be explicit about these conditioning factors and whether they should be contemporeneous or relative to the lifecycle, be made on an ex-ante basis or ex-post. In practice this is not the case. Each method and each survey question either implicitly or explicity conditions on different factors, whether it is hiring standards, performance requirements, relative prices, etc. It is unclear which method is to be preferred, and importantly the different measures only correlate imperfectly suggesting that measurement error is a concern once these measures are used for analysis.

\section{Incidence}

In this section we describe findings regarding the incidence of overschooling and underschooling. We start with the incidence of overschooling and underschooling at an aggregate level, and the patterns of these incidences across countries and over time. We then discuss the systematic differences that exist in the measured incidence of overschooling and underschooling due to the use of different measures of required schooling. Finally we turn to overschooling and underschooling at the level of individual workers. Which individual characteristics correlate significantly with overschooling and underschooling, and how persistent is the individual overschooled or underschooled status over time?

\subsection{Aggregate incidence}

Most studies dealing with overschooling report the incidence of overschooling and underschooling observed in the dataset that is used for the analysis. We collected many of these studies and Table 1 reports the (unweighted) means and medians of the reported shares of overschooled and underschooled workers. ${ }^{14}$ The first row reports these statistics for all studies together, in the next rows we report the means and medians for different continents, for time periods, by measure of required schooling and by gender.

The overall means reported by existing studies is 30 percent for the share of overschooled workers and 26 percent for the share of underschooled workers. For the share of overschooled workers the median is equal to the mean, for the share of underschooled workers the median of the shares reported by existing studies is somewhat below the mean. This indicates that outliers do not play a major role.

The share of overschooling is on average larger in studies that report results for the US/Canada than elsewhere, while the share of underschooled is on average

\footnotetext{
${ }^{14}$ We report the median to check to what extent the mean is sensitive to outliers.
} 
Table 1. Incidence of overschooling and underschooling

\begin{tabular}{|c|c|c|c|c|}
\hline & \multicolumn{2}{|c|}{ Fraction underschooled } & \multicolumn{2}{|c|}{ Fraction overschoolec } \\
\hline & Mean & Median & Mean & Median \\
\hline All studies & 0.26 & 0.21 & 0.30 & 0.30 \\
\hline \multicolumn{5}{|l|}{ By continent } \\
\hline$\overline{\text { Asia }}$ & 0.21 & 0.24 & 0.26 & 0.29 \\
\hline Australia & $\mathrm{n} / \mathrm{a}$ & $\mathrm{n} / \mathrm{a}$ & 0.08 & 0.08 \\
\hline Europe & 0.31 & 0.26 & 0.30 & 0.28 \\
\hline Latin America & 0.21 & 0.17 & 0.24 & 0.18 \\
\hline US/Canada & 0.16 & 0.16 & 0.37 & 0.35 \\
\hline \multicolumn{5}{|l|}{ By decade } \\
\hline $1970 \mathrm{~s}$ & 0.12 & 0.12 & 0.40 & 0.40 \\
\hline $1980 \mathrm{~s}$ & 0.23 & 0.21 & 0.30 & 0.32 \\
\hline $1990 \mathrm{~s}$ & 0.23 & 0.20 & 0.24 & 0.25 \\
\hline $2000 \mathrm{~s}$ & 0.49 & 0.50 & 0.39 & 0.40 \\
\hline \multicolumn{5}{|l|}{ By measure of $S^{r}$} \\
\hline Direct self-assessment & 0.10 & 0.10 & 0.33 & 0.33 \\
\hline Firm's recruitment & 0.15 & 0.15 & 0.19 & 0.19 \\
\hline Job analysis & 0.30 & 0.32 & 0.34 & 0.29 \\
\hline Mean & 0.15 & 0.15 & 0.16 & 0.13 \\
\hline Mode & 0.27 & 0.27 & 0.31 & 0.30 \\
\hline Quinn\&Rubb & 0.14 & 0.14 & 0.14 & 0.14 \\
\hline Self-assessment & 0.32 & 0.22 & 0.37 & 0.33 \\
\hline \multicolumn{5}{|l|}{ By gender } \\
\hline Female & 0.21 & 0.19 & 0.28 & 0.31 \\
\hline Both & 0.35 & 0.36 & 0.34 & 0.31 \\
\hline Male & 0.21 & 0.19 & 0.28 & 0.30 \\
\hline
\end{tabular}

Source: Database constructed from existing studies. 
somewhat larger in studies dealing with European countries than in studies dealing with other countries. This goes against economic priors since education is more subsidized and labor markets are arguably more imperfect in Europe. Both factors would lead to higher levels of overeducation in Europe compared to America. There appears to be a decline in reported overschooling form the 1970s to the 1990s. This on the other hand is consistent with the literature on skill-biased technical change. In the 2000s there is suddenly a sharp increase. This increase is, however, solely attributable to the shares reported in the study by Galasi (2008). As we discussed in Section 3, this study employs a somewhat different method to measure required schooling.

Studies reveal no systematic difference between the reported shares of over/underschooled men and women. Strangely enough, studies that report results for men and women together, tend to find larger shares of over/underschooled workers.

Finally, the fractions of over- and underschooled workers reported in different studies, varies greatly with the method that was used to measure required schooling. The methods using workers' self-assessment or the information from job analysts find shares of overschooling of over 30 percent, the same is true for the mode method. The mean method - which uses the 2 standard deviations bandwidth, finds much lower shares of overschooled (and underschooled) workers. These results support concerns over measurement error.

\subsection{Individual level - determinants}

Many studies estimate probit or similar binary outcome models of the determinants of overschooling and underschooling. The specification of these models varies widely between studies, complicating the comparison of the resulting estimates. There is typically little motivation of why some variables are included as controls and not others. An additional complication is that some of the included regressors such as tenure are potentially endogenous. More or less consistent findings across studies are that young people, women, migrants and people who are unmarried are more likely to be overschooled.

Gender The higher incidence of overschooling amongst women has been addressed in Frank (1978). His explanation is that when the men are the prime income earners in a household and when the choice of location is determined by the man's labor market prospects, women are necessarily more restricted, and this may translate in an increased probability to be overschooled. 
Age Older workers are less likely to be overschooled than their younger colleagues. This fact is consistent with search theory which predicts that workers are increasingly in better matches, but also with the theory of career mobility where workers who are overschooled in their first job have a higher probability to be promoted. It is also consistent with the view that the labor market rewards workers' entire bundle of human capital in which extra schooling can compensate for lack of experience. The observed age effect is also consistent with a gradual upgrading of schooling requirements.

Ethnicity The number of studies inquiring the relation between ethnicity and overschooling is limited (Green et al. (2007) and Battu et al. (2004) are exceptions). This is probably partially due to problems of comparibility of schooling in the country of origin to schooling in the country of residence. When minorities have not been educated in other countries, a rationale for higher overschooling incidence amongst minority groups runs similar to the rationales for women and young people. They may be more geographically restricted, and/or they may need the extra schooling to compensate for other shortages in their human capital bundle, such as proficiency in the native language. Of course, higher overschooling incidence among minorities may also reflect plain labor market discrimination.

Ability Another determinant of being overschooled may be a lower level of ability. The studies that have access to ability measures find that ability and overschooling (given the level of actual schooling) are indeed negatively correlated.

Chevalier and Lindley (2009) construct a measure of unobserved ability as the residual from a first-job earnings equation capturing all observed characteristics of an individual including job characteristics that affect wages over the control variables included. Including these residuals should then proxy for time invariant fixed unobservable characteristics. Estimates from multinomial logit models show that a one standard deviation increase in the unobservable component reduces the probability to be apparently overschooled by 2.9 percentage points, while it reduces the probability to be genuinely overschooled by 3.7 percentage points. These changes should be compared to base probabilities of 19.6 percent and 14.9 percent, respectively.

Green and McIntosh (2007) use data from the 2001 Skill Survey in the UK to examine the relation between being over/underqualified and the extent to which respondents report that they use their skills. Respondents were asked how much they agreed with the statement: "In my current job I have enough opportunities to use the knowledge and skills that I have" and "How much of your past experience , skills and abilities can you make use of in your present job?". If the respondent 
(strongly) disagreed with the statement or answered (very) little to the second question, s/he was recorded as overskilled. Likewise respondents who (strongly) agreed with the statement "I would perform better in my current job if I possessed additional knowledge and skills", were recorded as underskilled. Green and McIntosh report that the correlation coefficient of being overqualified and overskilled is only 0.20. Less than half of the overqualified employees report that they have skills and abilities that they are not using in their job. Among those who are not overqualified, this percentage equals $28 \%$. Even stronger is the finding for underqualified workers: they are not more or less likely than the non underqualified workers to report being underskilled. Green and McIntosh interpret this a evidence that these employees have gained skills through other routes after the end of their schooling (p.432).

Very similar results are reported by Allen and Van der Velden (2001) using data from the Dutch wave of the Higher Education and Graduate Employment in Europe project. The respondents graduated in 1990/1 and were interviewed at the end of 1998. For example, of the respondents with a higher vocational degree and who found a job matching their education level, 13\% report that their skills are underutilized. Among the respondents with the same education but with a job below their education level, this percentage equals $21 \%$.

Green et al. (1999) find that individuals who had higher scores in a math test when aged 16 were significantly less likely to be overeducated in their working lives, a $10 \%$ higher score on the mathematics test is associated with a $2 \%$ lower probability of being overeducated. Using the English data from the International Adult Literacy Suvey, they also find that individuals with low quantitative skills are more likely to be overeducated. Using German data, Buchel and Pollmann-Schult (2001) find that a poor grade on the school leaving certificate has a strong effect on the probability of overeducation for those graduating with a vocational degree (after controlling for selection effects). ${ }^{15}$

\subsection{Individual level - dynamics}

Overschooling is not necessarily a permanent state. For a better understanding of the overschooling phenomenon it is helpful to know more about its persistence at an individual level. Is 30 percent of the workforce permanently overschooled, or is a larger fraction overschooled for a shorter while and is being overschooled just a stage in workers' careers?

\footnotetext{
${ }^{15}$ See also Battu et al. (1999) (who control for the degree class and institution type in the UK), Dolton and Vignoles (2000) and Green and Zhu (2010) (who look at degree classifications and universities' reputation).
} 
Sicherman and Galor (1990) developed a theory of career mobility that can partially explain overschooling. In their model individuals may accept a lower-level job in which the direct return to schooling is lower if in those jobs, for a given level of schooling, the probability of promotion is higher.

To test their model, Sicherman and Galor estimate for 24 different occupations the effect of education on wages and the effect of education on the probability of upward career mobility. They find that the estimated effects are negatively correlated: occupations with a higher wage return to education have on average a smaller effect of education on upward mobility.

Sicherman and Galor (1990) claim that their model implies that "it will be rational for some individuals to spend a portion of their working careers in occupations that require a lower level of schooling than they have acquired" (p.177). This is explored in Sicherman (1991). Using PSID data for 1976 and 1978, he finds that being overschooled indeed has a positive impact on upward mobility. The size of this impact is however quite small. Some of the overschooled workers move upwards, but a large fraction remains overschooled. Various studies corroborate that for many workers overschooling persists. Although this is consistent with substantial mobility constraints on the part of workers, it is difficult to reconcile this with a structural population of underschooled workers. A more likely explanation seems that workers are and stay overschooled because they lack the necessary skills to perform more demanding jobs.

Bauer (2002)uses the German GSOEP data from 1984 to 1998 to analyze the returns to overschooling and underschooling in a panel data context. He does not report in detail the evolution of the mismatch status over time. From the information that he provides, it is evident however that rather few employees in Germany change their mismatch status. Using the mean method of Verdugo and Verdugo $5.3 \%$ of the observations change their mismatch status, while this percentage is $16.2 \%$ when using the mode-index. This implies relatively few changes, especially if one realizes that some of the variation in the realized match method is artificial. A worker who does not change his own schooling level and keeps the same job can still can still change his overschooling status if the mean (mode) schooling level in his occupation changes. Bauer is aware of the fact that the small numbers of a change in the mismatch status cast doubts on whether the wage effects of educational mismatch could be identified in the fixed effects model. ${ }^{16}$

Rubb (2003a) uses data from 1992/93 and 1995/99 waves of the Current Population Survey to document the dynamics of overschooling in the US. He measures

\footnotetext{
${ }^{16}$ We discuss these results in Section 5 .
} 
over/underschooling from realized matches (using Verdugo and Verdugo's mean method) and reports incidence rates of overschooling around 0.14. Rubb reports an annual ouflow from overschooling to adequately schooled of a bit under 0.2. Outflow rates out of overschooling are slightly higher for women than for men, decrease with age, and are not different for recession and expansion years. Rubb concludes that overschooling is not solely a short-run phenomenon that only exists when individuals gain experience or search for a new job.

Battu et al. (1999) examine two cohorts of higher education graduates in the United Kingdom. One cohort graduated in 1985, the other in 1990. The 1985 cohort was interviewed 1, 6 and 11 years after graduation; the 1990 cohort 1 and 6 years after graduation. Mismatch is measured by responses to the question: "Was the degree gained in 1985 or 1990 a requirement in the job specification for your main employment (including self-employment)?". For men the fractions of correctly matched workers all circle around 60 percent, while women the fraction goes up from less than 55 percentone year after graduation to just above 60 percent five years later. These fractions hide some movement into and out off correct matches; between 65 and 70 percent of the workers ever had a job that required their degree. One potential caveat of this study is that some people indicate that they move from a job that requires their degree to a managerial job that does not require their degree. This indicates that part of the "mismatched" workers is not really mismatched.

Mavromaras et al. (2009) analyze the Australian HILDA Survey 2001-2006. The sample consists of 15 to 64 -year-olds. They consider employees who report that they do not use many of their skills in their current job. This is different from the standard overschooling measure in the sense that it considers skill use and not educational attainment. Workers are classified as moderately or severely overskilled (and well matched). In the bottom half of the education distribution about one third of the workers is moderately and 19 percent severely overskilled. In the top half of the education distribution these numbers are 27 and 10 percent respectively. They drop however the moderately overskilled from the sample, thereby ignoring transitions from severely overskilled and well matched to moderately overskilled. Average transition rates per year are not reported (but are probably low). They estimate dynamic random effects probit models and find substantial state dependence. When stratifying by education they find that persistence is especially high for individuals with a higher education degree. ${ }^{17}$

Careful and systematic study of the incidence and dynamics of overschooling has received relatively little attention compared to the return estimates we review

\footnotetext{
${ }^{17}$ See also Lindley and McIntosh (2008), Dolton and Vignoles (2000) and Frenette (2004).
} 
in the next section. This is somewhat unfortunate as this could have increased our understanding of what is actually being measured. Our reading of the cross-sectional evidence on the incidence and persistence of overschooling is that although part of it is frictional, it mostly appears to correlate with unobserved skills.

\section{$5 \quad$ Impact on earnings}

The workhorse model in the overeducation literature is the extended version of the Mincerian wage equation introduced by Duncan and Hoffman (1981). Denote the standard Mincerian wage equation as:

$$
\ln w_{i}=\delta_{a} S_{i}^{a}+x_{i}^{\prime} \beta+\epsilon_{i}
$$

where $w_{i}$ is individual $i$ 's wage, $S_{i}^{a}$ attained years of schooling and $x_{i}$ a vector of control variables including experience and experience squared. $\delta_{a}$ is the return to (attained) education. Duncan and Hoffman divided $S^{a}$ into three components: the years of schooling required for the job $\left(S^{r}\right)$, and the difference between attained and required years, which is labeled years of overeducation (or surplus years) if attained schooling exceeds required schooling $\left(S^{\circ}\right)$ and which is labeled years of undereducation (or deficit years) if attained schooling falls short of required schooling $\left(S^{u}\right)$. The following identity therefore holds

$$
S_{i}^{a} \equiv S_{i}^{r}+\underbrace{\max \left(0, S_{i}^{a}-S_{i}^{r}\right)}_{S_{i}^{o}}-\underbrace{\max \left(0, S_{i}^{r}-S_{i}^{a}\right)}_{S_{i}^{u}} .
$$

Duncan and Hoffman replace $S^{a}$ in the Mincerian wage equation by these three components and allows them to have different effects on wages. The wage equation then reads:

$$
\ln w_{i}=\delta_{r} S_{i}^{r}+\delta_{o} S_{i}^{o}+\delta_{u} S_{i}^{u}+x_{i}^{\prime} \beta+\varepsilon_{i}
$$

where $\delta_{r}, \delta_{o}$ and $\delta_{u}$ are the returns to required-, over- and under-schooling, respectively.

An attractive feature of equation (3) is that it nests the standard human capital equation (2) as a special case. By imposing the restriction $\delta_{r}=\delta_{o}=-\delta_{u}$ it is straightforward to statistically test whether the Duncan and Hoffman specification fits the data better than the standard Mincer equation.

Another specification that is nested in the Duncan and Hoffman specification imposes the restriction $\delta_{o}=\delta_{u}=0$ which implies that only the job requirements 
matter for the wage. This is consistent with the Thurow's job competition model in which marginal productivity is a fixed characteristic of the job and independent of the worker (see Section 6.3 below). Wages are also assumed to be related to the job rather than to the worker. There is no claim of equality between wages and marginal productivity and it is not clear how wages are determined.

From the perspective of an individual who has to decide on the optimum amount of schooling the ex ante return $\delta_{a}$ is the more interesting parameter. Separate information on the parameters $\delta_{r}, \delta_{o}$ and $\delta_{u}$ is only interesting for an individual who knows whether s/he will end up in a job below/above her/his attained schooling level. Alternatively the separate parameters may also convey relevant information about the risk involved in the schooling decision.

An often cited (and heavily criticized) contribution to the overeducation literature is Verdugo and Verdugo (1989). They estimated the returns to overschooling and underschooling using a specification that differed in three important ways from the specification used by Duncan and Hoffman (1981). ${ }^{18}$ First, they measured required schooling through the mean method (see Section 3). Second, instead of including years of over/underschooling, they included dummies for being over/underschooled. And third, instead of required years of schooling they control for completed years of schooling in the regression. Confusingly, Verdugo and Verdugo discuss their findings as if they controlled for required instead of completed education. In their critiques, neither Cohn (1992) nor Gill and Solberg (1992) clearly point out that this is why Verdugo and Verdugo find effects of opposite sign. ${ }^{19}$ As Hartog (2000) argues: "[b]uilding up a body of comparable research, over time and place, would be facilitated by deleting this specification." (p.139).

A special case of the Verdugo and Verdugo specification naturally arises when considering the impact of overeducation on earnings of university graduates. This is an intensively studied topic in the United Kingdom (examples include Battu et al., 1999; Chevalier, 2003; Chevalier and Lindley, 2009; Dolton and Vignoles, 2000; Dolton and Silles, 2008). Also studies from the UK that do not exclusively deal with university graduates are often not comparable to studies that apply the Duncan and Hoffman specification as these studies measure education in terms of qualification levels instead of years of education.

Before we review the findings that have been obtained in studies reporting estimates from Duncan and Hoffman's specification in Subsection 5.3, we first discuss problems concerning omitted variable bias and measurement error. In our view,

\footnotetext{
${ }^{18}$ Surprisingly, Verdugo and Verdugo do not refer to Duncan and Hoffman's paper.

${ }^{19}$ It is straightforward to show that when estimating $\ln w_{i}=\alpha_{a} S^{a}+\alpha_{o} S^{o}+\alpha_{u} S^{u}+x^{\prime} \beta+\varepsilon_{i}$ one obtains estimates such that $\alpha_{a}=\delta_{r}, \alpha_{o}=\delta_{o}-\delta_{r}$ and $\alpha_{u}=\delta_{u}+\delta_{r}$.
} 
neither problem has been addressed satisfactorily in the overeducation literature. This makes interpretation of the findings less straightforward.

\subsection{Omitted variable bias}

Since the early 1990s identification issues have been a central theme in labor economics and in the economics of education (see Meghir and Rivkin (ming) for a review in the context of the economics of education). Developments in this area have almost entirely been ignored in the overeducation literature. This is not because identification issues are trivial in this sub-field. Clearly if $\epsilon_{i}$ and $S_{i}^{a}$ in equation (2) are correlated - as many returns to schooling studies suggest (see Card, 1999 and Ashenfelter et al., 1999 for surveys) - then there is no reason to assume that this would not be the case for the error term and the schooling components in Duncan and Hoffman's equation. Hence, also $\varepsilon_{i}$ and $S_{i}^{r}, S_{i}^{o}$ and $S_{i}^{u}$ will be correlated. The endogeneity problem is likely to be even more severe in the context of equation (3) than in the context of equation (2). Not only are estimates biased because of the non-random assignment of individuals to completed schooling levels, we now also have to deal with the non-random assignment of individuals to required schooling levels. Even if completed schooling is randomly assigned - or if we have credible instrumental variables for completed schooling - estimates of $\delta_{r}, \delta_{o}$ and $\delta_{u}$ will still be biased when workers are not randomly assigned to job requirements. And vice versa, when workers are randomly assigned to job requirements - or if we have credible instruments for required schooling -, these estimates will still be biased when workers are not randomly assigned to completed schooling levels.

Addressing these endogeneity problems is far from trivial. This is illustrated by Korpi and Tahlin (2009), one of the few studies using instrumental variable methods to estimate returns to over/underschooling. Korpi and Tahlin instrumented the three schooling components in Duncan and Hoffman's specification using number of sibings, place of residence during childhood, economic problems in the family of origin and disruption in family of origin. Not only are there indications that these instruments are weak, but one may question the validity of these exclusion restrictions.

Since there is more than one endogenous variable one must also be careful to verify the rank conditions. If instruments are motivated as instruments for completed years of schooling, they cannot serve as instruments for required schooling, overschooling and underschooling. This is easily seen by considering the following simplified model (dropping individual subscripts, intercepts and covariates for 
convenience):

$$
\begin{aligned}
\ln w & =\delta_{r} S^{r}+\delta_{o}\left(S^{a}-S^{r}\right)+\varepsilon \\
S^{a} & =\alpha_{1} z_{1}+\alpha_{2} z_{2}+u_{a} \\
S^{r} & =\beta S^{a}+u_{r}
\end{aligned}
$$

where $z_{1}$ and $z_{2}$ are (valid) instruments for $S^{a}$, and $u_{a}$ and $u_{r}$ are error terms. Equation (4) is a simplified version of Duncan and Hoffman's wage equation in which years of overschooling and years of underschooling are restricted to have symmetric effects on wages. Equation (6) reflects that $S^{r}$ may vary with $S^{a}$; higher educated people are more likely to end up in higher qualified jobs.

Substituting equation (5) into equation (6) and the resulting equation along with equation (5) into equation (4), gives us the reduced form wage equation:

$$
\ln w=\left(\delta_{r} \beta+\delta_{o}-\beta\right) \alpha_{1} z_{1}+\left(\delta_{r} \beta+\delta_{o}-\beta\right) \alpha_{2} z_{2}+\tilde{\varepsilon}
$$

where $\tilde{\varepsilon}$ collects the remaining terms. While we can obtain estimates for $\alpha_{1}$ and $\alpha_{2}$ from equation (5) and for $\beta$ from equation (6), the two terms in parentheses in equation (7) are identical and will not suffice to identify $\delta_{r}$ and $\delta_{o}$ separately. This changes when one of the instruments (or a third instrument $z_{3}$ ) has an independent effect on required schooling.

Hence for instrumental variable techniques to be applicable in this context (where required schooling depends on actual schooling) we do not only need an instrument for completed schooling, but also for required schooling. This severely limits the potential of instrumental variable methods to estimate the returns to overschooling: While researchers have been reasonably successful finding and applying instruments for completed years of schooling, finding instruments for required schooling is even more challenging.

As an alternative method to address the endogeneity problem, several papers have applied fixed effects techniques (Bauer, 2002; Dolton and Vignoles, 2000; Dolton and Silles, 2008; Korpi and Tahlin, 2009; Lindley and McIntosh, 2008; Tsai, 2010). ${ }^{20}$ Fixed effects estimates of the returns to over/underschooling are identified from persons who have changed educational level, job level or both. In both cases it needs to be the case that relevant unobservables are time-invariant. Take as an example a person who increases her level of completed schooling between waves. She may have been devoting time to study before the change occurred. If this unobserved change

\footnotetext{
${ }^{20}$ Many of these papers employ data for the UK and as a consequence do not estimate a specification with years of overschooling but with overschooling dummies.
} 
in study time also has an impact on wages, fixed effects estimates will be biased.

In practice fixed effects estimates will mostly rely on job changes for identification since people rarely change schooling after having entered the labor market. A person experiencing a change in the level of schooling required for the job, will therefore probably have changed jobs. Job changes can however be preceded, accompanied or followed by many other changes that are unobserved and affect wages. In such cases the strict exogeneity assumption that is necessary for fixed effects estimates to be consistent fails.

As another alternative approach to address endogeneity problems, McGuinness (2007) applies propensity score matching. As the identifying assumption is essentially the same as under ordinary least squares (no endogeneity conditional on observables), it is not surprising that he finds very similar estimates. His claim that this approach addresses omitted variable problems is in our view not realistic. At best, his results show that previous findings obtained from OLS are not attributable to common support problems.

The above discussion does not imply that overeducation researchers are not aware of the fact that estimated returns to overeducation may reflect differences across people in terms of other unobserved components of their human capital stock or of their motivation. The insight that people may have acquired more schooling than would normally be required for their job to compensate for a shortage in some other human capital components such as experience or ability, motivated the work of for instance Chevalier (2003); Allen and Van der Velden (2001) and Green and McIntosh (2007). It does imply, however, that it is extremely difficult to obtain credible estimates of causal effects of being over/underschooled. And, as we have argued in Section 2, obtaining estimates of causal impacts is crucial for the results from Duncan and Hoffman's wage equation to be useful.

\subsection{Measurement error}

Another concern in the literature on the returns to schooling is attenuation bias due to measurement error in the years of schooling variable. Given the discussion in Section 3 regarding the problems surrounding the measurement of required schooling, this issue is likely to be even more important when it comes to the estimation of the returns to required schooling. Moreover, both overschooling and underschooling are measured as a difference between two possibly mismeasured schooling levels. It is well known that differencing leads to exacerbation of measurement error problems and is akin to the measurement error problem in returns to schooling studies that use data from twins. 
As discussed in Section 4, different methods to measure required schooling present rather different results for the incidence of adequately, over and undereducated workers. At the same time, it has been noted that the method used to measure required schooling does not seem to have a large influence on the estimated returns despite these differences in incidence. This apparent consistency has led some commentators to conclude that measurement error bias is not an issue in the estimation of (3). This is of course a fallacy. The difference in incidence indicates that at least one required schooling variable is measured with error. As a consequence at least one set of estimates will be biased (and different from others if they are measured correctly). But since estimates based on the various measures give similar results these estimates all need to be biased.

Only a few studies have made attempts to address the issue of measurement error explicitly in the context of returns to required, overschooling and underschooling. Robst (1994) and Dolton and Silles (2008) use instrumental variables methods, and Tsai (2010) uses a minimum distance approach.

To better understand the role of measurement error in (3), let $D_{i}$ equal 1 if individual $i$ is overeducated and zero otherwise. We can rewrite equation (3) as follows (dropping control variables)

$$
\ln w_{i}=\delta_{r} S_{i}^{r}+\delta_{o}\left(S_{i}^{a}-S_{i}^{r}\right) D_{i}+\delta_{u}\left(S_{i}^{r}-S_{i}^{a}\right)\left(1-D_{i}\right)+\epsilon_{i}
$$

We assume that only $S^{r}$ is measured with error

$$
\tilde{S}_{i}^{r}=S_{i}^{r}+u_{i}
$$

where classical measurement error corresponds to the case in which $S_{i}^{r}$ and $u_{i}$ are independent. The classical measurement error assumption typically fails when variables are bounded. To see this note that, in the case of (required) schooling, when $\tilde{S}_{i}^{r}$ is the highest possible schooling level then $u_{i}$ must be negative. Similarly, when $\tilde{S}_{i}^{r}$ is the lowest possible level then $u_{i}$ can only be positive. As a consequence the measurement error $u_{i}$ will be negatively correlated with the true value $S_{i}^{r}$. Where classical measurement error leads to attenuation bias, the negative covariance leads to bias in the opposite direction.

It has been shown, in the case of single mismeasured regressors, that with nonclassical measurement error OLS estimates tend to be biased towards zero as long as the covariance between the measurement error and the variable is not stronger than the variance of the measurement error (Black et al., 2000). In this case the OLS estimate would serve as a lower bounds on the true effect. When there is a 
very strong negative correlation between the measurement error and the true value, the OLS estimate is also biased and can even change sign (Aigner, 1973).

An additional complication of measurement error in $S_{i}^{r}$ in the context of Equation (8), is that it will also lead to measurement error in $S_{i}^{o}$ and $S_{i}^{u}$. This happens both directly and through classification error with respect to the overeducation status $D_{i}$. The resulting measurement error will, again, be non-classical.

Substituting (9) in (8) we get:

$$
\ln w_{i}=\delta_{r} \tilde{S}^{r}+\alpha_{o} \underbrace{\left(S_{i}-\tilde{S}_{i}^{r}\right) \tilde{D}_{i}}_{\tilde{S}_{i}^{o}}+\delta_{u} \underbrace{\left(\tilde{S}_{i}^{r}-S_{i}\right)\left(1-\tilde{D}_{i}\right)}_{\tilde{S}_{i}^{u}}+\tilde{\epsilon}
$$

where

$$
\tilde{\epsilon}=\epsilon-u\left(\delta_{r}-\delta_{o} D_{i}+\delta_{u}\left(1-D_{i}\right)\right)+\left(\delta_{o}+\delta_{u}\right)\left(S_{i}-\tilde{S}_{i}^{r}\right)\left(D_{i}-\tilde{D}_{i}\right)
$$

and $\tilde{D}_{i}$ is the misclassified overschooling indicator. There are now two channels which affect our estimates in the presence of measurement error. First there is the bias channelled by $u$ in $\tilde{\epsilon}$. This can attenuate the estimate, but also lead to a bias in the opposite direction in case of a negative correlation between the mesaurement error and $S^{r}$. The second source of bias comes from classification bias $\left(D_{i}-\tilde{D}_{i}\right)$.

The standard method to correct for bias resulting from classical measurement error is instrumental variables. This is the approach of Robst (1994) and Dolton and Silles (2008). When measurement error is non-classical, instrumental variables is however also biased. To see why, note that any instrument that is correlated with required/under/overschooling will also be correlated with the residual in (10) since $\operatorname{cov}\left(S^{r}, u\right) \neq 0$. It can be shown that with a single mismeasured regressor the IV estimate will be biased upwards and represents an upper bound (Black et al., 2000). In the context of (10) there are three mismeasured variables, where the measurement error is not mutually independent and it is unclear whether the results of Black et al. (2000) carry over.

As an illustration of these issues consider Robst (1994) who recognized early the potential importance of measurement error. He uses one measure of required schooling as an instrument for the other (and vice versa). Of the two measures one is based on workers' assessment and the other on the GED estimate of required education based on three digit Census codes for occupations. The dataset that Robst uses is the 1985 wave of the PSID. The first thing to note is that only $53 \%$ of the observations is classified in the same category (adequately educated, overeducated, undereducated) on both measures. This implies that at least one of the required 
schooling measures is plagued by substantial measurement error.

Robst instrumented self-assessed required schooling, overschooling and underschooling by required schooling, overschooling and underschooling based on the GED measure of required schooling (and vice versa). The return to required schooling as measured by the worker's assessment increases from 0.07 to 0.09 (using required schooling according to the GED measure as an instrument). For the opposite instrumentation the return hardly changes (from 0.08 to 0.09 ). The return to overschooling however changes drastically. Using OLS the estimated return to a year of overschooling is about 0.05 using both measures of required schooling. When instrumenting one for the other, these returns drop to about -0.02 and are not statistically significant.

Where Robst (1994) estimates the full Duncan and Hoffman specification with three potentially mismeasured variables, Dolton and Silles (2008) analyze a sample of graduates from a UK university where, by definition, all hold the same level of education and can only be overschooled. As a consequence they estimate a wage equation with only a single overeducation dummy $D_{i}$. They find that university graduates who report to be overschooled in their first job earn less than their nonoverschooled counterparts with an estimated coefficient of -0.16 (s.e. 0.05). The IV estimate increases (in absolute value) as expected to -0.41 (s.e. 0.10). As graduates progress in their career the wage penalty associated with overschooling increases. The corresponding OLS estimate of the overeducation coefficient for the current job is -0.35 (s.e. 0.05 ) with the IV estimate at -0.66 (s.e. 0.10). In both cases the IV estimate is about twice the size of the OLS estimate. Dolton and Silles (2008) also control for individual fixed effects, and obtain very similar results.

In a recent paper Tsai (2010) uses the PSID data to estimate fixed effects versions of (3). The author reports negative point estimates on overschooling (and positive point estimates on underschooling) because the used specification deviates from (3) in that it controls for actual rather than required schooling. It is therefore necessary to take the appropriate transformation of the coefficients to compare the estimates to those of the literature. Doing this we see a return to required schooling that drops from about 0.11 in the pooled OLS to 0.02 in the fixed effects models. Similar changes are observed for the coefficients on overschooling and underschooling. The pooled OLS estimate on overschooling is 0.076 and the fixed effect estimate is 0.015 . For underschooling these numbers are -0.057 and -0.010 .

One interpretation of Tsai's results is that the drop in the estimates when using fixed effects estimation is caused by measurement error. To address this question Tsai implements a numerical procedure that assumes classical measurement error 
on required schooling but allows for classification bias that might result of this. Unfortunately it is unclear whether the implemented estimation procedure produces consistent estimates. Moreover, the estimated variance of the measurement error (about 16) is six times larger than the variance of (mis)measured required schooling itself (about 2.6) which should be a logical impossibility.

\subsection{Findings}

This final subsection summarizes the estimates of the returns to required, over and underschooling reported in the overeducation literature. Given the unsolved issues concerning omitted variable bias and measurement error, we do not claim that these estimates represent causal effects.

It is probably not only the simplicity of Duncan and Hoffman's specification that has been an important factor for its popularity, but also the results originally reported by Duncan and Hoffman (1981) are likely to have contributed. Using the 1976 wave of the PSID, they report a return to completed years of education equal to 0.058 for white men. When they break completed education down into its three components, they find a return of 0.063 to a year of education required for the job, a return of 0.029 for a year of surplus education and a negative return of -0.042 for each year of deficit education. The return to an overeducated year is significantly and substantially lower than the return to a required year of education, suggesting that it is indeed worthwhile to break completed education down.

Many studies have replicated Duncan and Hoffman's study using different data and (not always) different measures for required schooling. In Table $\mathrm{A}$ in the Appendix, we tabulate the findings of many of these studies. Table 2 summarizes the findings. To average the estimates of returns to required schooling and over/underschooling from various studies, we have used a weighting method which has been developed in the meta-analysis literature (see Raudenbush (1994) or Van Ewijk and Sleegers (2010) for details).

The first row in the table shows that the return to a year of required schooling is around 0.09, to a year of overschooling more or less half of that, and a year of underschooling results in a wage penalty of again around half of the return to a required year of schooling.

The other rows of Table 2 break the sample of results down by continent, decade, method to measure required schooling, estimation method and gender. The results by continent suggest that the absolute values of the returns are a bit larger in the Asian countries in our sample than in Europe and in the US/Canada whereas differences between European countries and North America are small. Over time we 
Table 2. Returns to required schooling $\left(\delta_{r}\right)$, overschooling $\left(\delta_{o}\right)$ and underschooling $\left(\delta_{u}\right)$

\begin{tabular}{|c|c|c|c|c|}
\hline & $\delta_{r}$ & $\delta_{o}$ & $\delta_{u}$ & $\mathrm{~N}$ results \\
\hline All studies & $0.089(0.003)$ & $0.043(0.002)$ & $-0.036(0.002)$ & $151 / 151 / 143$ \\
\hline \multicolumn{5}{|l|}{$\underline{\text { By continent }}$} \\
\hline$\overline{\text { - US/Canada }}$ & $0.083(0.006)$ & $0.046(0.004)$ & $-0.027(0.004)$ & $32 / 32 / 26$ \\
\hline - Latin America & 0.075 & 0.041 & -0.034 & \\
\hline - Europe & $0.076(0.003)$ & $0.038(0.003)$ & $-0.035(0.004)$ & $94 / 94 / 94$ \\
\hline - Asia & $0.135(0.008)$ & $0.052(0.003)$ & $-0.042(0.004)$ & $18 / 18 / 18$ \\
\hline - Australia & 0.105 & 0.05 & & \\
\hline \multicolumn{5}{|l|}{$\underline{\text { By decade }}$} \\
\hline$-1970 \mathrm{~s}$ & $0.079(0.007)$ & $0.043(0.004)$ & $-0.037(0.008)$ & $13 / 13 / 9$ \\
\hline$-1980 \mathrm{~s}$ & $0.084(0.005)$ & $0.048(0.003)$ & $-0.036(0.003)$ & $37 / 37 / 37$ \\
\hline$-1990 \mathrm{~s}$ & $0.113(0.008)$ & $0.038(0.004)$ & $-0.026(0.007)$ & $41 / 41 / 38$ \\
\hline$-2000 \mathrm{~s}$ & $0.095(0.004)$ & $0.046(0.003)$ & $-0.040(0.003)$ & $27 / 27 / 26$ \\
\hline \multicolumn{5}{|l|}{ By measure of $S^{r}$} \\
\hline - self assessment & $0.079(0.003)$ & $0.041(0.003)$ & $-0.034(0.003)$ & $68 / 68 / 66$ \\
\hline - job analysis & $0.075(0.004)$ & $0.043(0.002)$ & $-0.032(0.002)$ & $27 / 27 / 23$ \\
\hline - mean method & $0.108(0.009)$ & $0.041(0.007)$ & $-0.025(0.011)$ & $29 / 29 / 27$ \\
\hline - modal method & $0.101(0.009)$ & $0.054(0.004)$ & $-0.056(0.005)$ & $24 / 24 / 24$ \\
\hline \multicolumn{5}{|c|}{ By estimation method } \\
\hline - OLS & $0.092(0.003)$ & $0.043(0.002)$ & $-0.033(0.002)$ & $128 / 128 / 120$ \\
\hline - IV & $0.095(0.016)$ & $-0.031(0.028)$ & $-0.031(0.032)$ & $4 / 4 / 4$ \\
\hline$-\mathrm{FE}$ & $0.043(0.019)$ & $0.031(0.023)$ & $-0.040(0.022)$ & $5 / 5 / 5$ \\
\hline \multicolumn{5}{|l|}{ By gender } \\
\hline - Male & $0.090(0.005)$ & $0.047(0.003)$ & $-0.037(0.004)$ & $51 / 51 / 46$ \\
\hline - Female & $0.101(0.009)$ & $0.046(0.005)$ & $-0.042(0.006)$ & $35 / 35 / 32$ \\
\hline - Both & $0.077(0.004)$ & $0.035(0.004)$ & $-0.029(0.004)$ & $63 / 63 / 63$ \\
\hline
\end{tabular}

Source: Database constructed from existing studies. Means and their standard errors are obtained by weighting estimates with the inverse of their variance. See Harbord and Higgins (2004) for details. 
do not observe a consistent pattern. Only the 1990s are characterized by somewhat higher absolute values of the returns estimates. The differences in estimated returns between studies that use self-assessed measures of required schooling and studies that base their required schooling measure on job analysis, is indeed rather small. Studies that use the mean or mode method find larger returns on required schooling, and those based on the mode method also find larger absolute returns on overschooling and underschooling.

Differentiating estimated returns to the three components by different estimation methods indicates that studies that use IV tend to find a much lower return to overschooling than studies using OLS. Likewise studies using fixed effects are characterized by a lower return to required years of schooling. It should be noted though that the number of studies applying IV and fixed effects is rather small.

The final rows in Table 2 show that returns to different schooling components are not systematically different between men and women. Results based on data that combine information of men and women tend to report lower returns that are smaller (in absolute value). Table 3 presents the results from meta-regressions in which the estimated returns to the three schooling components are regressed on study characteristics. These results reiterate the patterns observed in Table 2 in a multivariate framework.

The quotes that we cited in Section 2 demonstrate that the types of results summarized in this subsection have been interpreted as causal effects of overeducation and undereducation on wages. Wording like: "a positive effect", "holding other characteristics constant", "not completely unproductive", "results in", "returns are very low" and "productivity is affected" are very explicit in that respect. Because of problems with omitted variable bias and measurment error, we believe that such interpretations are not warranted.

\section{Relation to labor market theories}

The incidence of over and underschooling and the pattern of estimated returns to required, over and underschooling have been interpreted in terms of various labor market theories. In this section, we give a brief summary of these interpretations, and the (sometimes) implicit assumptions made for these interpretations.

\subsection{Human capital}

According to Mincer's wage equation only the amount of attained schooling matters for wages. Since Duncan and Hoffman's wage equation nests Mincer's equation 
Table 3. Meta-regressions

\begin{tabular}{|c|c|c|c|}
\hline & $\delta_{r}$ & $\delta_{o}$ & $\delta_{u}$ \\
\hline Dummy Asia $=1$ & $\begin{array}{c}0.033^{* * *} \\
(0.009)\end{array}$ & $\begin{array}{c}0.010 \\
(0.008)\end{array}$ & $\begin{array}{c}-0.029^{* *} \\
(0.010)\end{array}$ \\
\hline Dummy Europe $=1$ & $\begin{array}{l}-0.011 \\
(0.008)\end{array}$ & $\begin{array}{l}-0.006 \\
(0.007)\end{array}$ & $\begin{array}{l}-0.013 \\
(0.009)\end{array}$ \\
\hline US/Canada, Mexico, Australia & reference & reference & reference \\
\hline Decade 1970 s & $\begin{array}{l}-0.015 \\
(0.012)\end{array}$ & $\begin{array}{c}-0.010 \\
(0.010)\end{array}$ & $\begin{array}{c}0.002 \\
(0.014)\end{array}$ \\
\hline Decade 1980s & $\begin{array}{c}-0.014^{*} \\
(0.007)\end{array}$ & $\begin{array}{l}-0.004 \\
(0.006)\end{array}$ & $\begin{array}{l}0.014^{*} \\
(0.007)\end{array}$ \\
\hline Decade 1990s & $\begin{array}{c}0.018^{* *} \\
(0.007)\end{array}$ & $\begin{array}{c}-0.015^{*} \\
(0.006)\end{array}$ & $\begin{array}{c}0.025^{* * *} \\
(0.007)\end{array}$ \\
\hline Decade 2000s & reference & reference & reference \\
\hline Measure Mean & $\begin{array}{c}0.003 \\
(0.007)\end{array}$ & $\begin{array}{l}-0.004 \\
(0.007)\end{array}$ & $\begin{array}{c}0.014 \\
(0.008)\end{array}$ \\
\hline Measure Job Analysis & $\begin{array}{c}-0.014^{*} \\
(0.007)\end{array}$ & $\begin{array}{c}0.007 \\
(0.006)\end{array}$ & $\begin{array}{l}-0.004 \\
(0.007)\end{array}$ \\
\hline Measure Mode & $\begin{array}{c}0.000 \\
(0.009)\end{array}$ & $\begin{array}{c}0.008 \\
(0.008)\end{array}$ & $\begin{array}{c}-0.010 \\
(0.008)\end{array}$ \\
\hline Measure Workers' Assessment & reference & reference & reference \\
\hline Fixed effects & $\begin{array}{c}-0.041^{* * *} \\
(0.011)\end{array}$ & $\begin{array}{l}-0.014 \\
(0.010)\end{array}$ & $\begin{array}{c}0.003 \\
(0.011)\end{array}$ \\
\hline Instrumental Variables & $\begin{array}{c}0.033 \\
(0.018)\end{array}$ & $\begin{array}{c}-0.084^{* *} \\
(0.031)\end{array}$ & $\begin{array}{l}-0.006 \\
(0.035)\end{array}$ \\
\hline OLS & reference & reference & reference \\
\hline Dummy Male=1 & $\begin{array}{c}0.001 \\
(0.007)\end{array}$ & $\begin{array}{c}0.010 \\
(0.007)\end{array}$ & $\begin{array}{l}-0.013 \\
(0.007)\end{array}$ \\
\hline Dummy Female $=1$ & $\begin{array}{c}0.012 \\
(0.008)\end{array}$ & $\begin{array}{c}0.010 \\
(0.007)\end{array}$ & $\begin{array}{c}-0.017^{*} \\
(0.007)\end{array}$ \\
\hline Dummy Both Genders=1 & reference & reference & reference \\
\hline Constant & $\begin{array}{c}0.089^{* * *} * \\
(0.008)\end{array}$ & $\begin{array}{c}0.043^{* * *} \\
(0.008)\end{array}$ & $\begin{array}{c}-0.024^{* * *} \\
(0.009)\end{array}$ \\
\hline$N$ & 151 & 151 & 143 \\
\hline
\end{tabular}

Source: Database constructed from existing studies. Each column gives the results from a different meta-regression in which studies' estimates are regressed on study characteristics. Each estimate is weighted by the inverse of its variance. See Harbord and Higgins (2004) for details. for details. 
as a special case, it is straightforward to test whether the restrictions implied by Mincer's equation can be rejected. This is a test of the joint equality: $\delta_{r}=\delta_{o}=-\delta_{u}$. Without exception, this restriction is rejected by the data. This has been interpreted as evidence against a simple version of the human capital model in which wages are solely determined by attained level of schooling independent of the job to which a worker has been assigned.

The results are, however, consistent with slightly adapated versions of the human capital model. A first possibility is that being in a job that requires less schooling than available, provides an investment opportunity. This idea has been formalized by Sicherman and Galor (1990). We discuss this contribution in more detail in the next subsection.

Also consistent with the human capital model is that overschooling substitutes for other components in a person's stock of human capital, such as training, experience and innate ability. The finding that overschooling is more prominent among younger workers is consistent with this. It is also consistent with the reported negative correlation between overschooling and measures of ability; see Section 4 .

\subsection{Career mobility}

Sicherman and Galor (1990) formalized the notion of career mobility as an explanation for the phenomenon of overeducation. They constructed a model of which the assumptions immediately imply that a worker with given innate ability may prefer to start in a job below his ability level if this is compensated by a higher probability to be promoted. According to Sicherman and Galor this implies that "individuals may consider a lower-level firm in which the direct return to schooling is lower if in those firms, for a given level of schooling, the probability of promotion is higher". To test this implication of their model, the authors estimate for 24 different occupations the effect of education on wages and the effect of education on the probability of upward career mobility. They find that the estimated effects are negatively correlated: occupations with a higher wage return to education have on average a smaller effect of education on upward mobility. This supports their model.

Sicherman and Galor (1990) also claim that their model implies that "it will be rational for some individuals to spend a portion of their working careers in occupations that require a lower level of schooling than they have acquired" (p.177). This implication is further explored in Sicherman (1991). He regresses an indicator for upward mobility on indicators for overschooling and underschooling, controlling for attained schooling, experience (squared) and some other observables. The results show positive coefficients for the overschooling and underschooling indicators and 
a negative coefficient for attained schooling. Although Sicherman summarizes his finding with respect to the overschooling coefficient as indicating that "overeducated workers are more likely to move to a higher-level occupation than workers with the required level of schooling.", the results from the specification that controls for experience (squared) suggest the opposite. Overeducated workers are more likely to move to a higher level-occupation than workers with the same level of attained schooling who are not over or undereducated. ${ }^{21}$ This calls into question why the overeducated invested in schooling; they earn more than the not adequately educated in the same occupation, but at the same time also have a lower promotion probability.

Sicherman also finds that underschooled workers are more likely to be promoted than someone with the same level of schooling working in an occupation requiring this schooling level (with the effect being even bigger than that of the overschooling dummy). This puzzling finding can be explained if the underschooling is highly correlated with unobserved ability.

\subsection{Job competition}

Thurow (1975) proposed a theory of job competition which stipulates that wages are solely determined by requirements of the job. Based on their attained schooling, workers are ranked in order of trainability, and the highest ranked workers is assigned to the highest ranked job. Attained schooling does, however, not affect earnings directly. This model implies the following testable restriction for Duncan and Hoffman's wage equation: $\delta_{o}=\delta_{u}=0$. These equalities are almost always rejected by the data.

Job competition is closely related to the notion of crowding out of lower educated workers by higher educated workers during recessions. Gautier et al. (2002) find no support for this process. Only for one out of six job complexity levels they find that firms upgraded their workforce in low employment years. As far as crowding out takes place, it is more outflow driven than inflow driven. While this result seems to contradict Thurow's model, the study finds at the same time that at a given level of job complexity workers with relatively many years of schooling are not more productive than their direct colleagues. The authors explain the difference between this results and the results in the overeducation literature by the fact that their analysis takes account of match specific effects. This means that workers with relatively many years of schooling (compared to other workers at the same

\footnotetext{
${ }^{21}$ The coefficient for years of attained schooling equals -0.0676 , and the coefficient of the overschooling dummy equals 0.2181 . Hence, if someone is more than $3(\approx 0.2181 / 0.0676)$ years overeducated, his probability to be promoted is smaller than that of the correctly educated workers in the same occupation.
} 
job level) select themselves into high wage firms. This results is consistent with Thurow's model, and points to the fact that estimation of Duncan and Hoffman's wage equation is not the correct approach to test Thurow's model.

\subsection{Signaling/screening}

Since the early 1970s, the human capital model has been contested by the signaling hypothesis of Spence (1973). According to Spence's original signaling model, investments in schooling are efficient from an individual's point of view, but do not affect a worker's productivity. Schooling does, however, still have a role in allocating the most productive workers to jobs in which they can be more productive. To the extent that this allocative role of schooling can be replaced by a less expensive selection mechanims, there is overinvestment in schooling. This source of overinvestment in schooling has not been addressed in the overeducation literature.

\subsection{Preferences}

The consumptive value of education may explain why people acquire more schooling than is optimal from a more narrow perspective of maximizing lifetime earnings. Since people may differ in their taste for schooling, some will overinvest more than others. If some people extract disutility from attending school, this may explain why some people underinvest in schooling. To our knowledge, this issue has been largely ignored in the economics of education literature. ${ }^{22}$

People may also differ in the degree to which they value leisure on the job. Jobs with lower skill requirements are likely to come with more leisure on the job for someone with a given skill level. The opposite would then hold for people working in a job above their acquired skill level. The significantly negative/positive impact of over/underschooling on job satisfaction reported by Hersch (1991); Korpi and Tahlin (2009); Verhaest and Omey (2006b) contradict this explanation.

Gottschalk and Hansen (2003) develop a simple model with two sectors (the college and the noncollege sector) and two types of workers (college and noncollege graduates). Both sectors produce according to a production function in which the two types of workers are perfect substitutes. The productivity of college graduates is more similar to that of noncollege graduates in the noncollege sector than in the college sector. Workers are allowed to have heterogeneous preferences with regard to

\footnotetext{
${ }^{22}$ Exceptions are Lazear (1977) and Oosterbeek and Van Ophem (2000). Using a Cobb-Douglas utility function $U=\ln N+\alpha \ln s$, the latter study finds that $\alpha$ is on average 1.1 and ranges between 0.24 and 1.68, implying that even those with the lowest taste for education extract positive utility from it.
} 
being empoyed in the two sectors. Some college graduates require a higher premium to work in the college sector than others. Gottschalk and Hansen show that in this framework, in equilibrium, some college workers voluntarily choose to work in the noncollege sector. Their overschooling (Gottschalk and Hansen avoid to use this term) does in this model, not signal a misallocation of resources or an involuntary assignment across sectors.

\subsection{Search and frictions}

The labor market does not operate frictionless, and over/underschooling can be the manifestations of frictions. Albrecht and Vroman (2002) proposed a matching model in which on-the-job search is not possible. They show that in that case, two types of equilibria can emerge: highly-educated workers match with skilled and with unskilled jobs, or highly-educated workers refuse to take unskilled jobs. Which of these equilibria emerges depends on the gap in productivity between skilled and unskilled jobs and on the share of high skilled workers in the workforce.

Gautier (2002) allows high-skilled workers to search on the job. In that case, the degree to which high skilled workers accept simple jobs depends on their relative productivity in such jobs, and on their quit rate. Dolado et al. (2009) analyze a model with on-the-job search very similar to that of Gautier, but allow wages to depend on aggregate labor market outcomes. Highly-educated workers may end up in unskilled jobs for which they are overqualified but are allowed to engage in on-thejob search on pursuit of a better job. Skill mismatch has in that case a transitory nature. This job-acceptance rule is very similar in spirit to the one proposed by Sicherman and Galor (1990). Here too, we may argue that the empirical regularity that overschooling is for many persistent, is at odds with these models.

\section{Conclusion}

This chapter surveyed the economics literature on overschooling. The initial motivation to study this topic were concerns about a strong increase in the number of college graduates in the early 1970s in the US and a concurrent decrease in the returns to college education. These concerns were fueled by Freeman's book "The Overeducated American". We reconstruct that fresh evidence that was published shortly after Freeman's book should have been sufficient to temper the concerns. Yet, not too long after, Duncan and Hoffman published their seminal paper that started the subfield of the economics of overeducation.

The main vehicle in this literature is an extended version of Mincer's wage equa- 
tion where actual years of schooling is broken down in years of overschooling, years of required schooling and years of underschooling. The additional estimates that this specification produces are not very useful from the perspective of the decision to invest in schooling - neither from an individual nor from an aggregate perspective. From both perspectives it is only the expected (private of social) return on completed schooling that counts. At best are the separate estimates informative about the riskiness of investments in schooling.

The efficiency implications of mismatch are interesting and to our knowledge nobody has pursued them to date. Potentially, estimates of returns to required schooling, overschooling and underschooling are informative about the costs of mismatch. Such estimates, together with information about the assignment of workers (by completed schooling) to jobs (by required schooling), could allow us to calculate by how much productivity (approximated by the wage sum) could increase by reallocating workers to jobs that require their schooling. Unfortunately, the estimates that have been produced are not suitable for such an exercise because the literature has not been able to separate the impact of mismatch from unobserved ability. Measurement error, which is already an issue for the estimation of the return to completed schooling, is probably much more problematic in the context of required schooling and over/underschooling and poses an additional hurdle to the consistent estimation of the effects of interest.

The micro overschooling literature was born out of an additional variable - required schooling - in the PSID. From that Duncan and Hoffman could construct measures of overschooling and underschooling at an individual level, which they could then loosely connect to concerns about overschooling at an aggregate level. From this start onwards, the overschooling literature has lacked substantive hypotheses. Instead results from Duncan and Hoffman's wage equation have been loosely interpreted in terms of existing theories. But we are reluctant to attach too much weight to these interpretations given that it is unclear to what extent the estimates are reliable.

Our overall conclusion regarding the contributions of the overschooling literature to our understanding of the functioning of labor markets and investment in education is rather pessimistic. The literature has produced dozens of estimates of the returns to required schooling, overschooling an underschooling. But although some studies express awareness that omitted variable (ability) bias and measurement error may be a concern, these issues have not been addressed is a satisfying way. As a result, the estimates that have been reported cannot be interpreted as causal. Consequently, the estimates are consistent with the plethora of interpretations reviewed in Section 
6. Our own reading of the evidence is that omitted variable bias is substantial and possibly explains the entire difference between returns to required schooling and overschooling and underschooling.

Ideally, a review like this one solves existing problems or at least provides a roadmap as how to proceed. Unfortunately, this chapter does not live up to that ideal. The overeducation/mismatch literature has for too long led a separate life of modern labor economics and the economics of education. We conclude that the conceptional measurement of overeducation has not been resolved, omitted variable bias and measurement error are too serious to be ignored, and that substantive economic questions have not been rigorously addressed. Hence new contributions seem only worthwhile if they include a serious attempt to tackle (at least one of) these issues.

\section{References}

Aigner, D. (1973). Regression with a binary independent variable subject to errors of observation. Journal of Econometrics, 1(1):49-50.

Alba-Ramirez, A. (1993). Mismatch in the Spanish labor market: overeducation? Journal of Human Resources, pages 259-278.

Albrecht, J. and Vroman, S. (2002). A matching model with endogenous skill requirements. International Economic Review, 43:283-305.

Allen, J. and Van der Velden, R. (2001). Educational mismatches versus skill mismatches: effects on wages, job satisfaction, and on-the-job search. Oxford Economic Papers, 53(3):434-452.

Ashenfelter, O., Harmon, C., and Oosterbeek, H. (1999). A review of estimates of the schooling/earnings relationship, with tests for publication bias. Labour Economics, 6:453-470.

Autor, D. and Katz, L. F. (1999). Changes in the wage structure and earnings inequality. In Ashenfelter, O. and Card, D., editors, Handbook of Labor Economics, Volume 3A, pages 1463-1555. Amsterdam: Elsevier-North Holland.

Battu, H., Belfield, C., and Sloane, P. (1999). Overeducation among graduates: A cohort view. Education Economics, 7(1):21-38.

Battu, H., Sloane, P., Building, E., Street, D., and Park, S. (2004). Over-education and ethnic minorities in Britain. Manchester School, 72(4):535-559. 
Bauer, T. (2002). Educational mismatch and wages: a panel analysis. Economics of Education Review, 21(3):221-229.

Beneito, P., Ferri, J., Molto, M. L., and Uriel, E. (1996). Over/undereducation and specific training in Spain: Complementary or substitute components of human capital? Palgrave.

Berg, I. (1970). Education and Jobs: The Great Training Robbery. Praeger.

Black, D., Berger, M., and Scott, F. (2000). Bounding Parameter Estimates with Nonclassical Measurement Error. Journal of the American Statistical Association, 95(451):739-747.

Büchel, F. and van Ham, M. (2003). Overeducation, regional labor markets, and spatial flexibility. Journal of Urban Economics, 53(3):482-493.

Card, D. (1999). Education and earnings. In Ashenfelter, O. and Card, D., editors, Handbook of Labor Economics. North Holland.

CEDEFOP (2010). The skill matching challenge; analysing skill mismatch and policy implications. Technical report, CEDEFOP.

Chevalier, A. (2003). Measuring over-education. Economica, 70(279):509-531.

Chevalier, A. and Lindley, J. (2009). Overeducation and the skills of UK graduates. Journal of the Royal Statistical Society: Series A, 172:307-337.

Clogg, C. (1979). Measuring Underemployment: Demographic Indicators for the United States. Academic Press.

Cohn, E. (1992). The Impact of Surplus Schooling on Earnings: Comment. Journal of Human Resources, 27:679-679.

Cohn, E. and Khan, S. (1995). The wage effects of overschooling revisited. Labour Economics, 2(1):67-76.

Cohn, E. and Ng, Y. (2000). Incidence and wage effects of overschooling and underschooling in Hong Kong. Economics of Education Review, 19(2):159-168.

Daly, M., Büchel, F., and Duncan, G. (2000). Premiums and penalties for surplus and deficit education Evidence from the United States and Germany. Economics of Education Review, 19(2):169-178. 
Dolado, J. J., Jansen, M., and Jimeno, J. F. (2009). On the job-search in a matching model with heterogeneous jobs and workers. Economic Journal, 119:200-228.

Dolton, P. and Vignoles, A. (2000). The incidence and effects of overeducation in the U.K. graduate labor market. Economics of Education Review, 19:179-198.

Dolton, P. J. and Silles, M. A. (2008). The effects of over-education on earnings in the graduate labour market. Economics of Education Review, 27(2):125 - 139.

Duncan, G. and Hoffman, S. (1981). The incidence and wage effects of overeducation. Economics of Education Review, 1(1):75-86.

Eckaus, R. (1964). Economic criteria for education and training. Review of Economics and Statistics, 46:181-190.

Frank, R. (1978). Why women earn less: the theory and estimation of differential overqualification. American Economic Review, 68(3):360-373.

Freeman, R. (1975). Overinvestment in college training? Journal of Human Resources, 10:287-311.

Freeman, R. (1976). The Overeducated American. Academic Press.

Frenette, M. (2004). The overqualified Canadian graduate: the role of the academic program in the incidence, persistence, and economic returns to overqualification. Economics of Education Review, 23(1):29-45.

Galasi, P. (2008). The effect of educational mismatch on wages for 25 countries. Budapest Working Papers on the Labour Market BWP - 2008/8.

Gautier, P. (2002). Unemployment and search externalities in a model with heterogeneous jobs and workers. Economica, 69:21-40.

Gautier, P., J. van den Berg, G., C. van Ours, J., and Ridder, G. (2002). Worker turnover at the firm level and crowding out of lower educated workers. European Economic Review, 46(3):523-538.

Gill, A. M. and Solberg, E. J. (1992). Surplus schooling and earning: a critique. Journal of Human Resources, 27:683-689.

Gladwell, M. (2008). Outliers; the story of success. Little, Brown and Company.

Gottschalk, P. and Hansen, M. (2003). Is the proportion of college workers in noncollege jobs increasing? Journal of Labor Economics, 21:449-471. 
Green, C., Kler, P., and Leeves, G. (2007). Immigrant overeducation: Evidence from recent arrivals to Australia. Economics of Education Review, 26(4):420-432.

Green, F. and McIntosh, S. (2007). Is there a genuine under-utilization of skills among the over-qualified? Applied Economics, 39:427-439.

Green, F., McIntosh, S., and Vignoles, A. (1999). Overeducation' and skills - clarifying the concepts. Technical report.

Green, F. and Zhu, Y. (2010). Overqualification, job dissatisfaction, and increasing dispersion in the returns to graduate education. Oxford Economic Papers, $\mathrm{xx}$ :forthcoming.

Groeneveld, S. and Hartog, J. (2004). Overeducation, wages and promotions within the firm. Labour Economics, 11(6):701-714.

Groot, W. (1993). Overeducation and the returns to enterprise related schooling. Economics of Education Review, 12:299-309.

Groot, W. (1996). The incidence of, and returns to overeducation in the UK. Applied Economics, 28(10):1345-1350.

Groot, W. and Maassen van den Brink, H. (1997). Allocation and the Returns to Over-education in the UK. Education Economics, 5(2):169-183.

Groot, W. and Maassen van den Brink, H. (2000). Overeducation in the labor market: A meta-analysis. Economics of Education Review, 19(2):149-158.

Halaby, C. (1994). Overeducation and skill mismatch. Sociology of Education, pages 47-59.

Hammack, F. M. (1978). Review: The "value" of a college education. The School Review, 86:669-679.

Harbord, R. and Higgins, J. (2004). Metareg: Stata module to perform metaanalysis regression. Statistical Software Components, Boston College Department of Economics.

Hartog, J. (2000). Over-education and earnings: where are we, where should we go? Economics of Education Review, 19(2):131-147.

Hartog, J. and Oosterbeek, H. (1988). Education, allocation and earnings in the Netherlands: Overschooling? Economics of Education Review, 7(2):185-94. 
Hartog, J. and Tsang, M. (1987). Estimating, testing and applying a comparative advantage earnings function for the us 1969-1973-1977. Research Memorandum 8709, Universiteit van Amsterdam, Department of Economics.

Hersch, J. (1991). Education Match and Job Match. Review of Economics and Statistics, 73(1):140-144.

Hung, C.-Y. (2008). Overeducation and undereducation in taiwan. Journal of Asian Economics, 19:125-137.

Kiker, B., Santos, M., and de Oliveira, M. (1997). Overeducation and undereducation: evidence for Portugal. Economics of Education Review, 16(2):111-125.

Korpi, T. and Tahlin, M. (2009). Educational mismatch, wages, and wage growth: Overeducation in Sweden, 1974-2000. Labour Economics, 16:183-193.

Lazear, E. P. (1977). Education: Consumption or production? Journal of Political Economy, 85:569-598.

Levin, H. M. (1977). Book review: The Overeducated American by Richard B. Freeman. Harvard Educational Review, 47:226-231.

Lindley, J. and McIntosh, S. (2008). A panel data analysis of the incidence and impact of over-education. Technical report, University of Sheffield.

Mavromaras, K., McGuinness, S., and Fok, Y. K. (2009). Overskilling dynamics and education pathways. Discussion Paper 4321, IZA.

McGoldrick, K. and Robst, J. (1996). Gender differences in overeducation: A test of the theory of differential overqualification. American Economic Review, 86:280284.

McGuinness, S. (2006). Overeducation in the labour market. Journal of Economic Surveys, 20(3):387-418.

McGuinness, S. (2007). How biased are the estimated wage impacts of overeducation? a propensity score matching approach. Applied Economics Letters, 15:145149.

Meghir, C. and Rivkin, S. G. (forthcoming). Econometric methods for research in education. In Hanushek, E., Machin, S., and Woessmann, L., editors, Handbook of the Economics of Education. Amsterdam: Elsevier-North Holland. 
Ng, Y. (2001). Overeducation and undereducation and their effect on earnings: evidence from Hong Kong, 1986-1996. Pacific Economic Review, 6(3):401-418.

Oosterbeek, H. and Van Ophem, H. (2000). Schooling choices: Preferences, discount rates, and rates of return. Empirical Economics, 25:15-34.

Oosterbeek, H. and Webbink, D. (1996). Over scholing, overscholing en inkomen. Economisch-Statistische Berichten, 81:240-241.

Quinn, M. and Rubb, S. (2006). Mexico's labor market: The importance of education-occupation matching on wages and productivity in developing countries. Economics of Education Review, 25:147-156.

Raudenbush, S. (1994). Random effects models. In Cooper, H. and Hedges, L., editors, The Handbook of Research Synthesis. New York, NY, US: Russell Sage Foundation.

Robst, J. (1994). Measurement error and the returns to excess schooling. Applied Economics Letters, 1:142-144.

Rubb, S. (2003a). Overeducation: a short or long run phenomenon for individuals? Economics of Education Review, 22(4):389-394.

Rubb, S. (2003b). Post-college schooling, overeducation, and hourly earnings in the United States. Education economics, 11(1):53-72.

Rumberger, R. (1987). The impact of surplus schooling on productivity and earnings. Journal of Human Resources, pages 24-50.

Santos, M. (1995). Education and earnings differentials in portugal. Ph.D. thesis, Porto University, Faculty of Economics, Porto.

Schøne, P. and Hardoy, I. (2009). Returns to pre-immigration education for nonwestern immigrants: Why so low? Working paper.

Sicherman, N. (1991). "Overeducation" in the labor market. Journal of Labor Economics, $9(2): 101$.

Sicherman, N. and Galor, O. (1990). A theory of career mobility. Journal of Political Economy, 98(1):169-192.

Sloane, P. (2003). Much ado About Nothing? What does the Overeducation Literature Really Tell us. In Büchel, F., De Grip, A., and Mertens, A., editors, 
Overeducation in Europe; Current issues in theory and policy, pages 11-45. Edward Elgar.

Slonimczyk, F. (2008). Skill mismatch and earnings: A panel analysis of the U.S. labor market. Working paper.

Smith, J. and Welch, F. (1978). The overeducated American? A review article. Technical report, Rand Corporation.

Spence, M. (1973). Job market signalling. Quarterly Journal of Economics, 87:355374.

Sullivan, T. (1978). Marginal Workers, Marginal Jobs: the Underutilization of American Workers. University of Texas Press.

Thurow, L. (1975). Generating inequality. Basic Books.

Tsai, Y. (2010). Returns to overeducation: A longitudinal analysis of the U.S. labor market. Economics of Education Review, 29(4):606 - 617.

Vahey, S. (2000). The great Canadian training robbery: evidence on the returns to educational mismatch. Economics of Education Review, 19(2):219-227.

Van der Meer, P. (2006). The validity of two education requirement measures. Economics of Education Review, 25:211-219.

Van der Meer, P. (2009). Investments in education: Too much or not enough? Economics Letters, 102:195-197.

Van der Velden, R. and Van Smoorenburg, M. (2000). The measurement of overeducation and undereducation: self-report vs job-analyst method. Les Cahiers de Lamas.

Van Ewijk, R. and Sleegers, P. (2010). The effect of peer socioeconomic status on student achievement: A meta-analysis. Educational Research Review, 5:134-150.

Van Smoorenburg, M. and Van der Velden, R. (2000). Overeducation and the effects on training and wages for school-leavers. Research Centre for Education and the Labour Market.

Verdugo, R. and Verdugo, N. (1989). The impact of surplus schooling on earnings: some additional findings. Journal of Human Resources, pages 629-643. 
Verhaest, D. and Omey, E. (2006a). Discriminating between alternative measures of over-education. Applied Economics, 38(18):2113-2120.

Verhaest, D. and Omey, E. (2006b). The impact of overeducation and its measurement. Social Indicators Research, 77(3):419-448.

Vieira, J. (1999). Evolution of wage structures in Portugal 1986-1992. Ph.D. thesis, Tinbergen Institute, University of Amsterdam. 


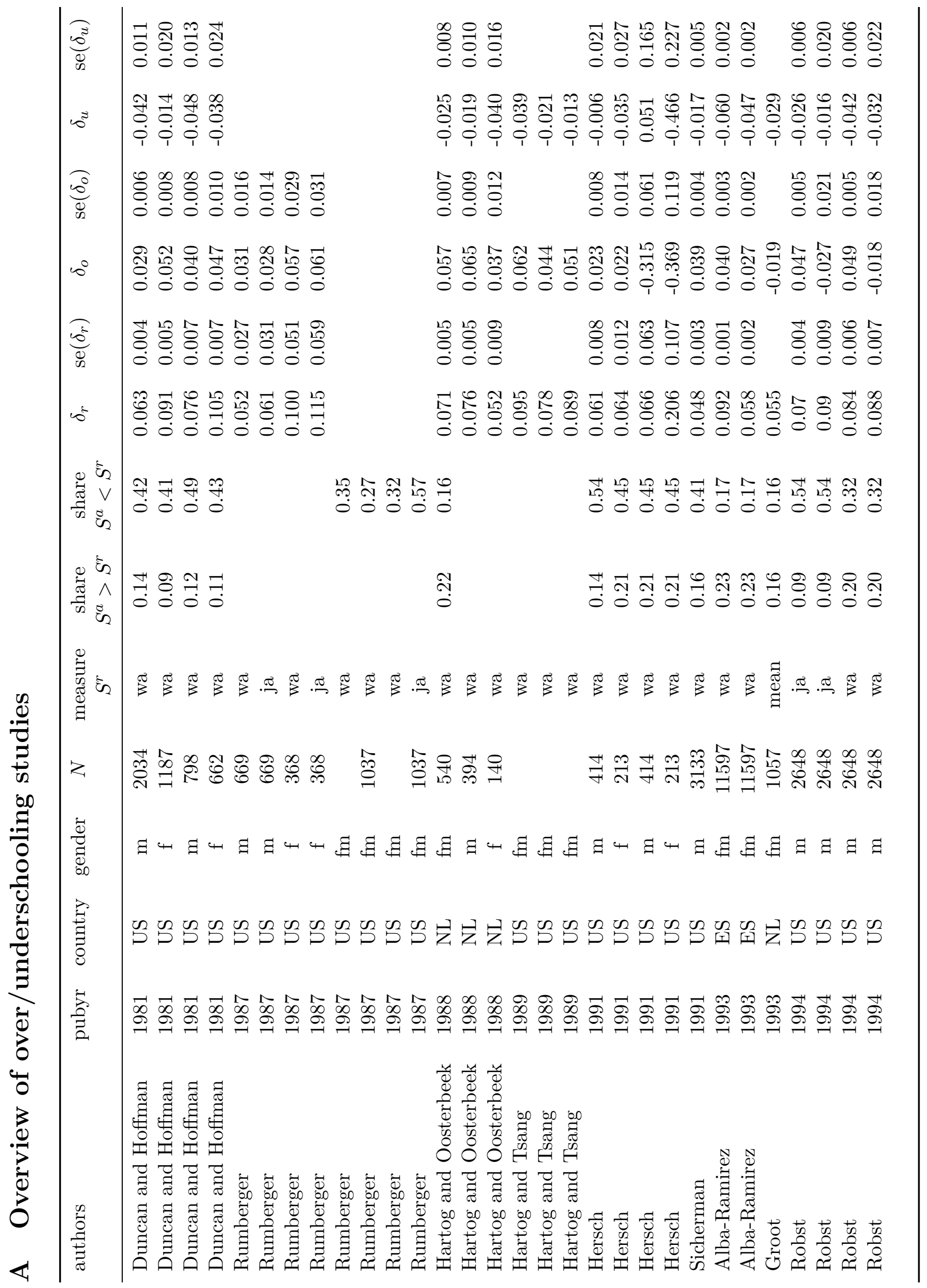




\begin{tabular}{|c|c|c|c|}
\hline$\overbrace{\substack{3 \\
d \\
\infty}}^{\infty}$ & $\mid \begin{array}{llll}20 & 20 & 2 & 0 \\
0 & 0 & 8 & 8 \\
0 & 0 & 0 \\
0 & 0 & 0 & 0\end{array}$ & 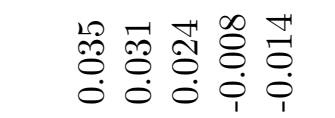 & 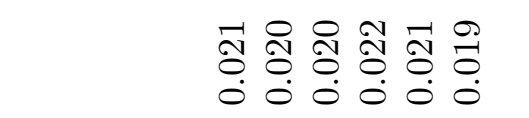 \\
\hline $0^{2}$ & 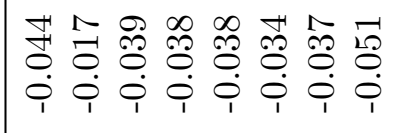 & 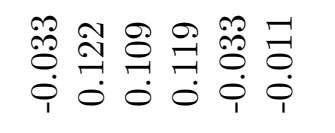 & 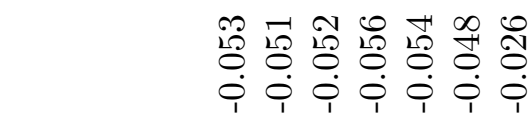 \\
\hline$\underset{\substack{0 \\
0 \\
\infty}}{0}$ & 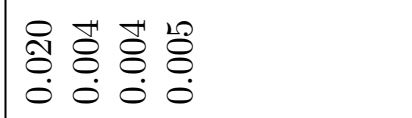 & 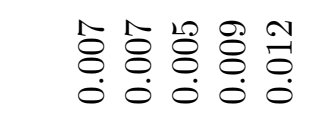 & 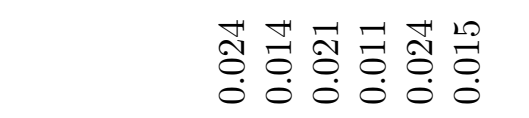 \\
\hline $10^{\circ}$ & 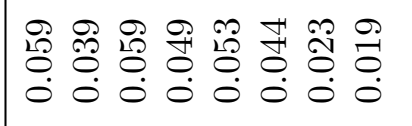 & 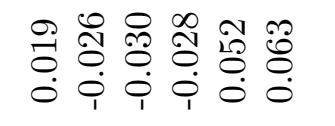 & 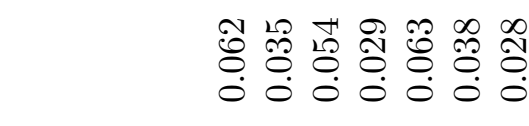 \\
\hline & 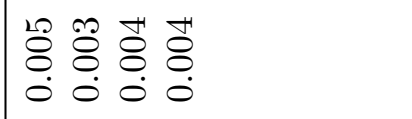 & 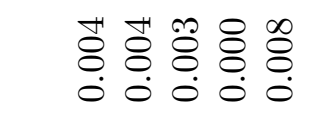 & 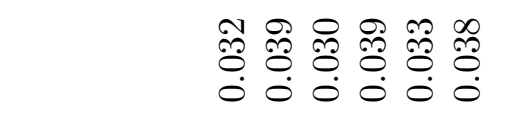 \\
\hline 10 & 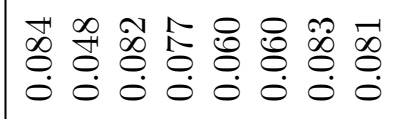 & 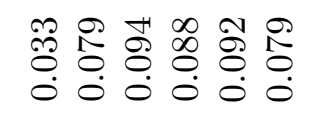 & 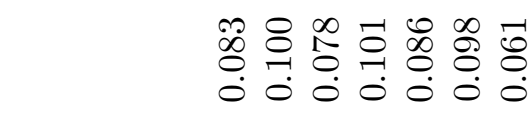 \\
\hline 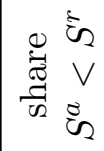 & 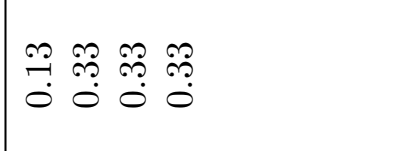 & $\stackrel{9}{\rightarrow} \stackrel{0}{1}=$ & 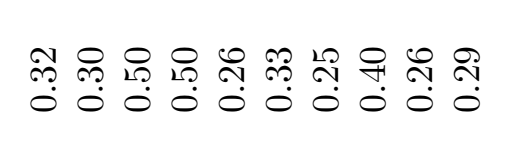 \\
\hline 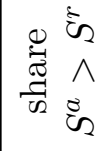 & r. & \begin{tabular}{lll}
0 & $\infty$ & 0 \\
\hdashline & 0 & 0 \\
0 & 0 & 0
\end{tabular} & 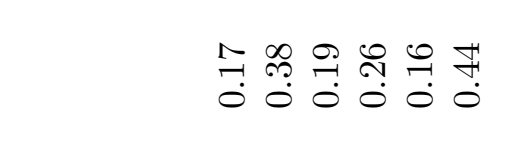 \\
\hline 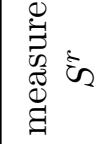 & 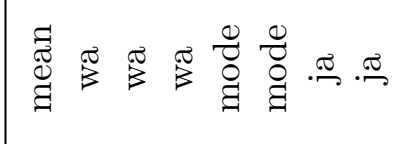 & 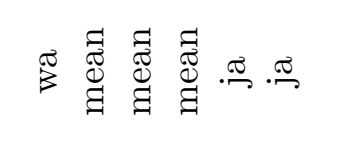 & 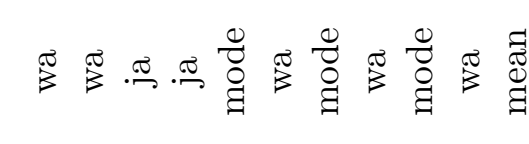 \\
\hline$z$ & 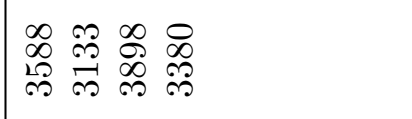 & 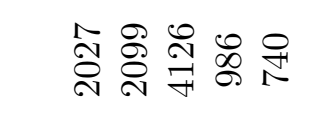 & 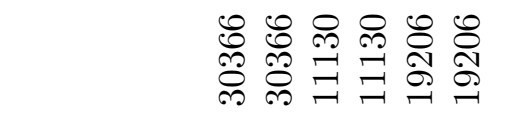 \\
\hline$\underset{0}{\tilde{0}}$ & 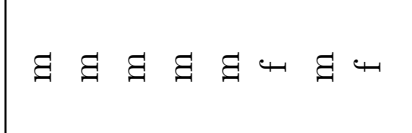 & 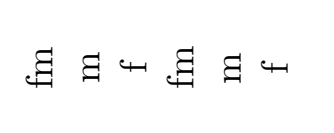 & 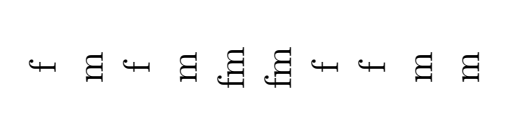 \\
\hline 莺 & 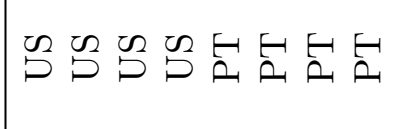 & 㴈吕吕㐊 & 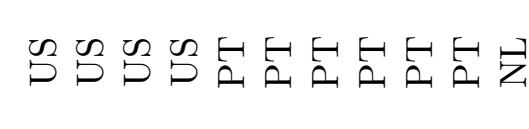 \\
\hline$\frac{\vec{c}}{\overrightarrow{2}}$ & 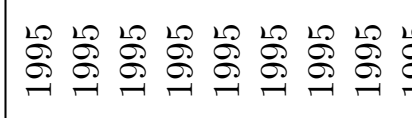 & 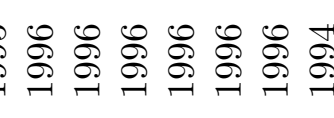 & 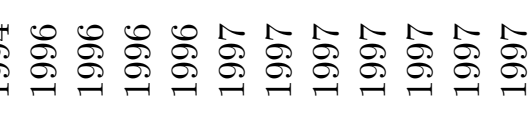 \\
\hline$\frac{\infty}{0}$ & 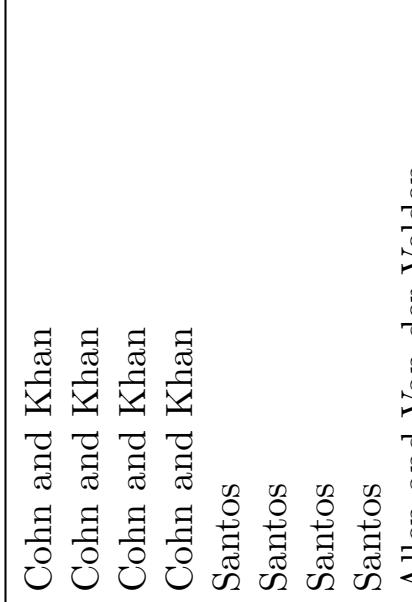 & 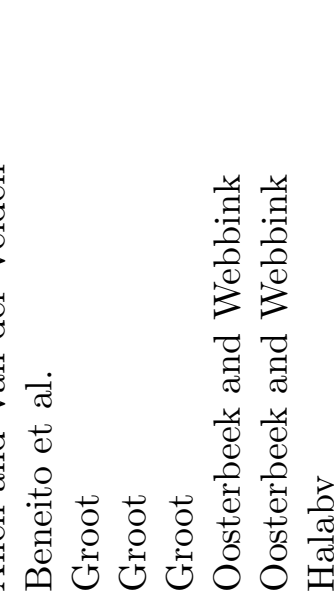 & 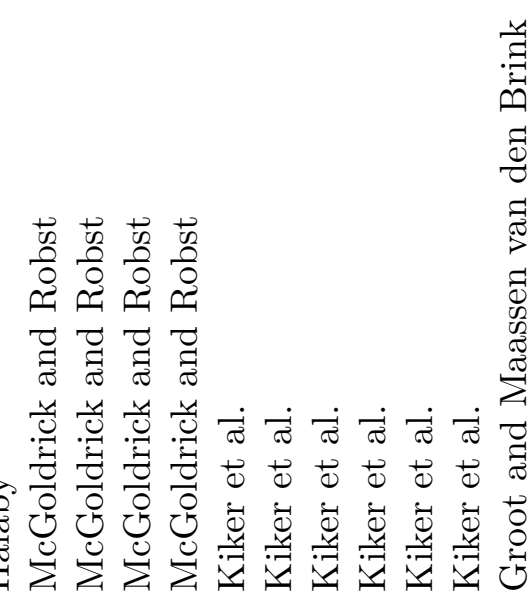 \\
\hline
\end{tabular}




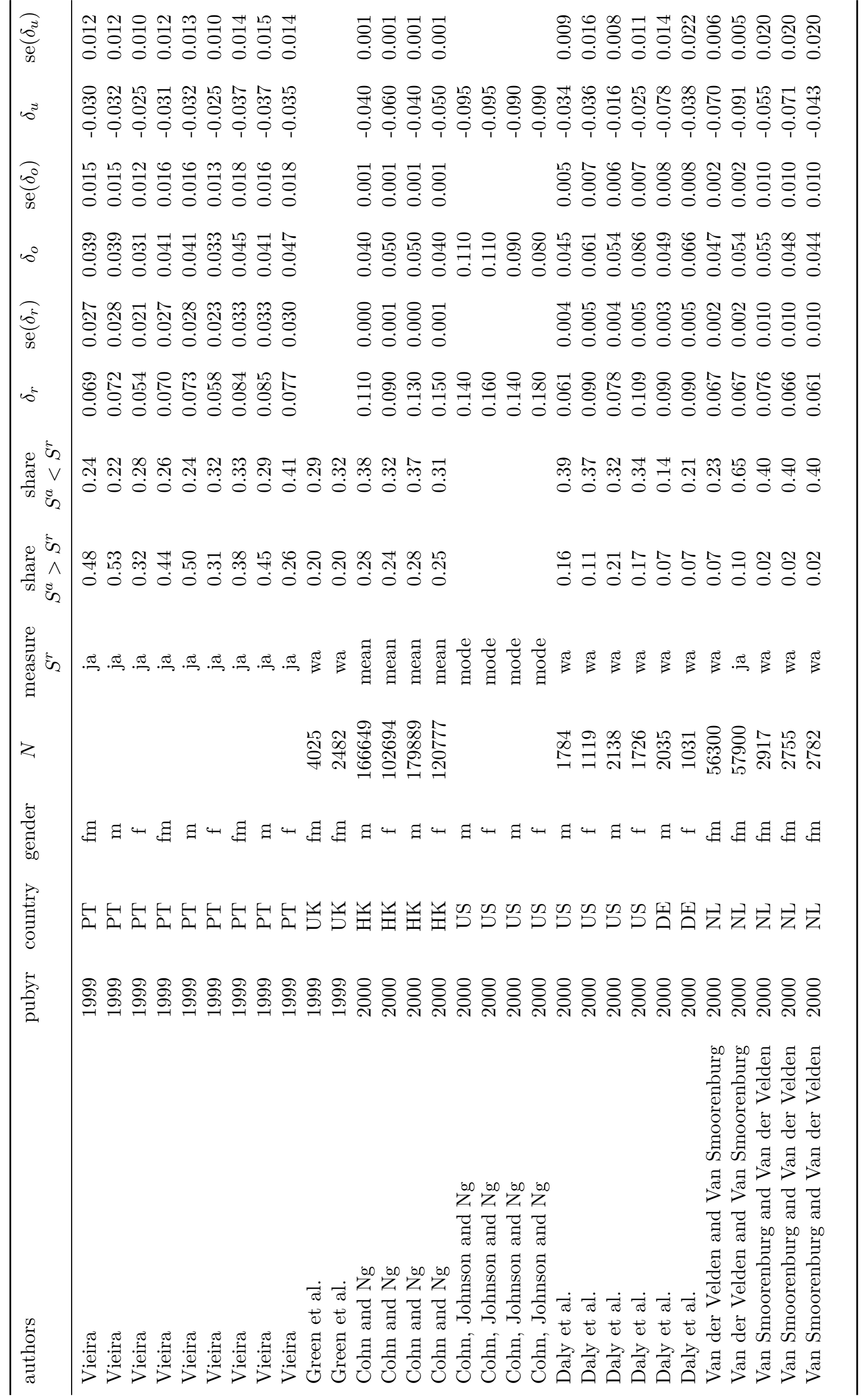




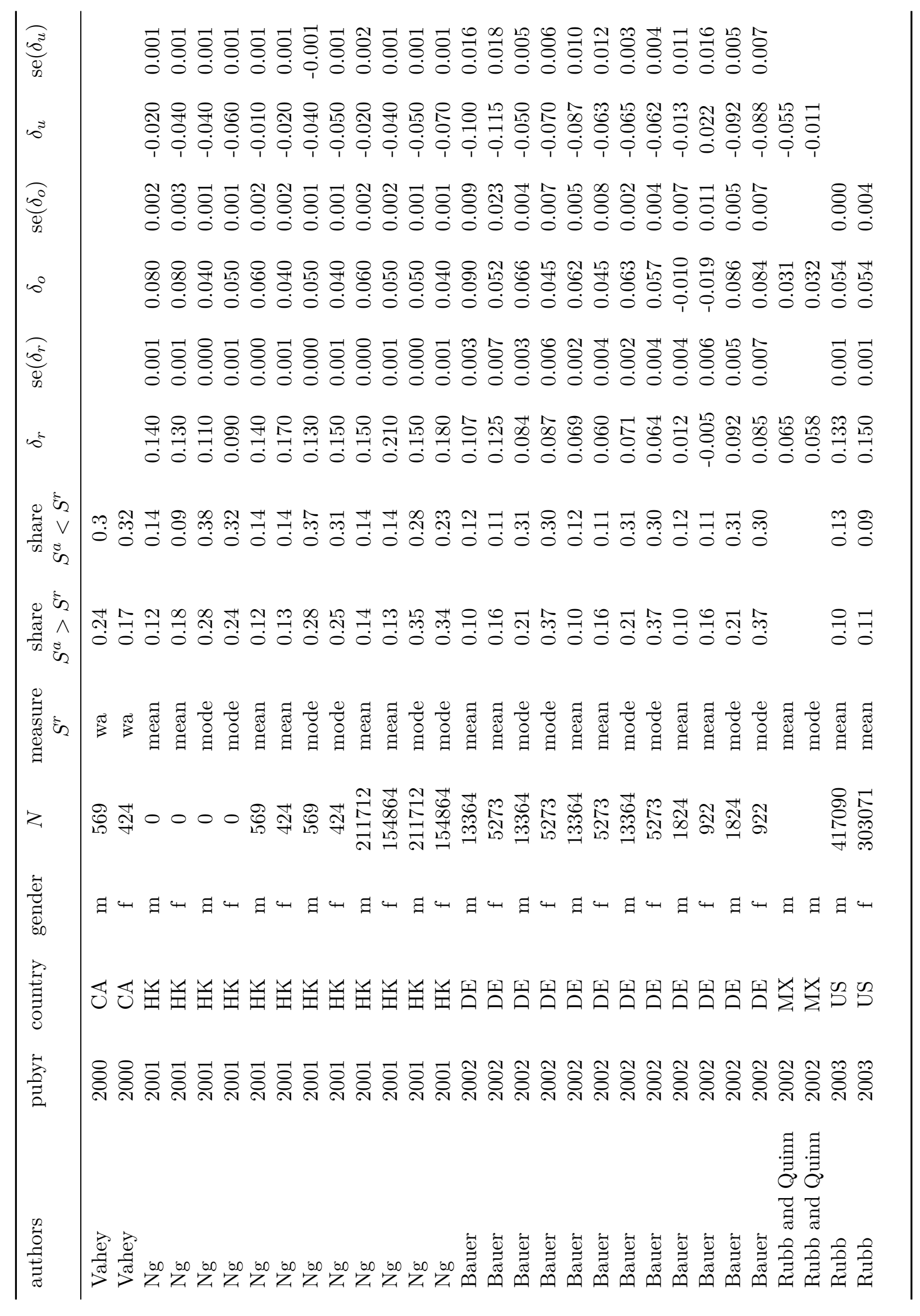




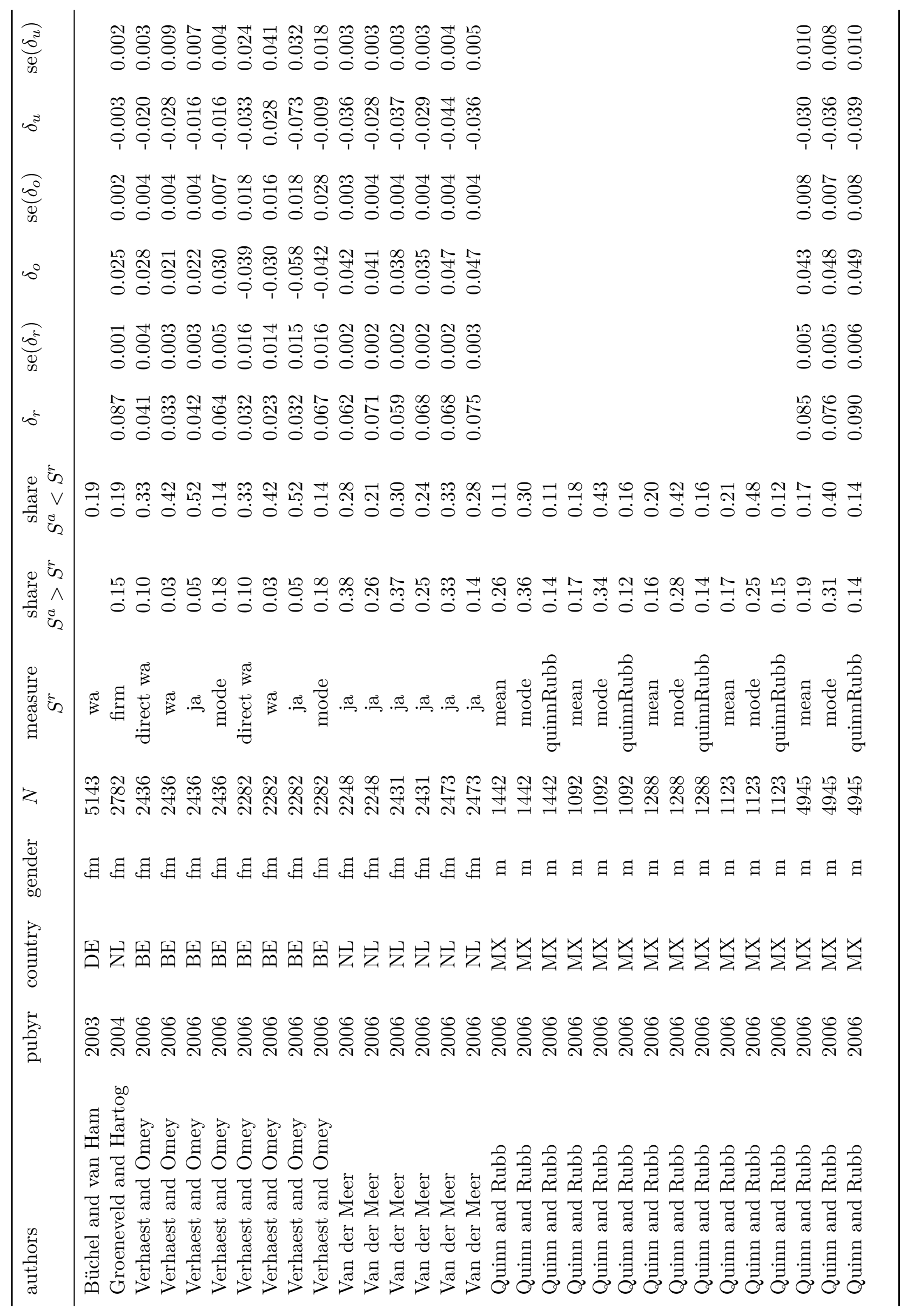




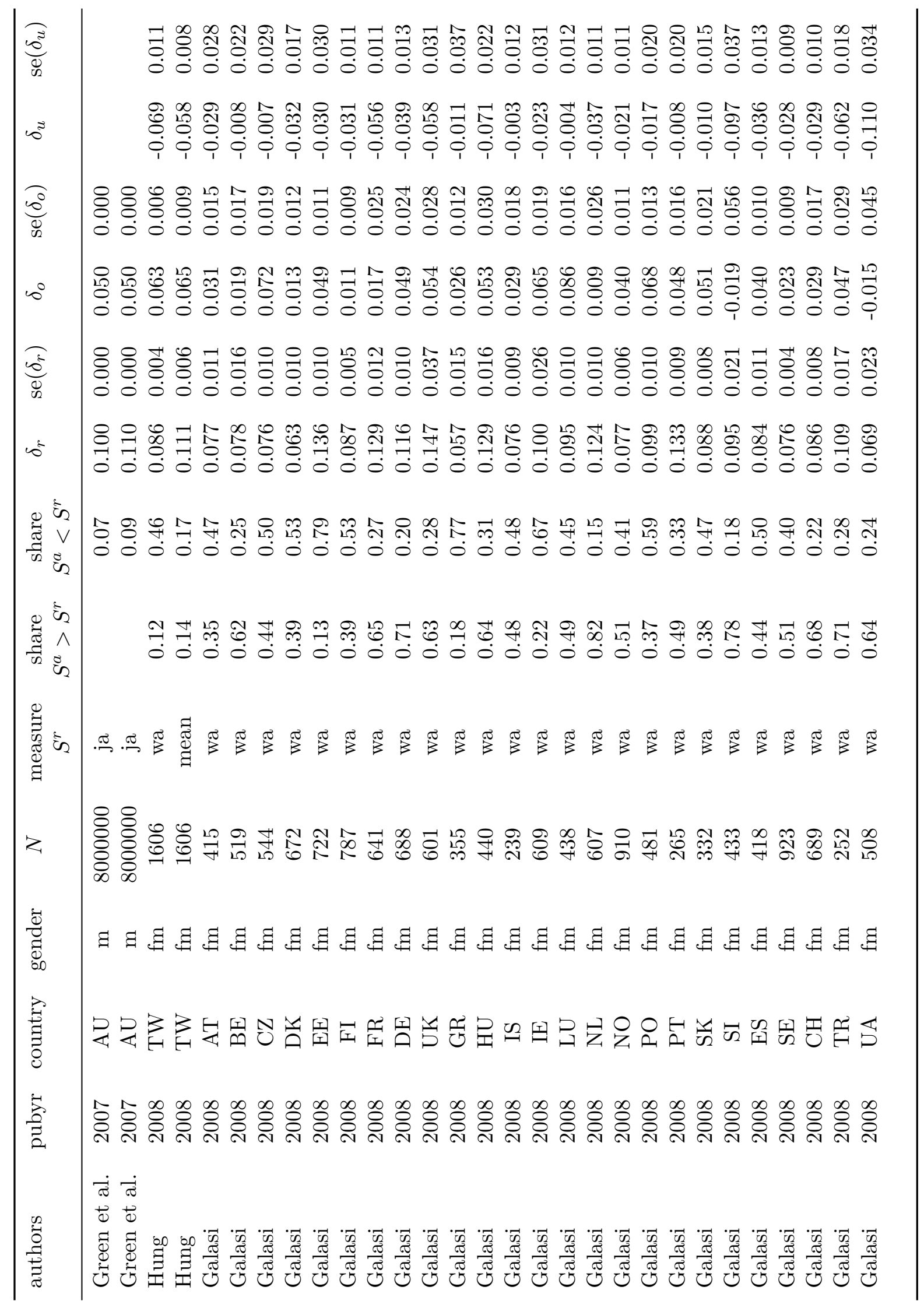




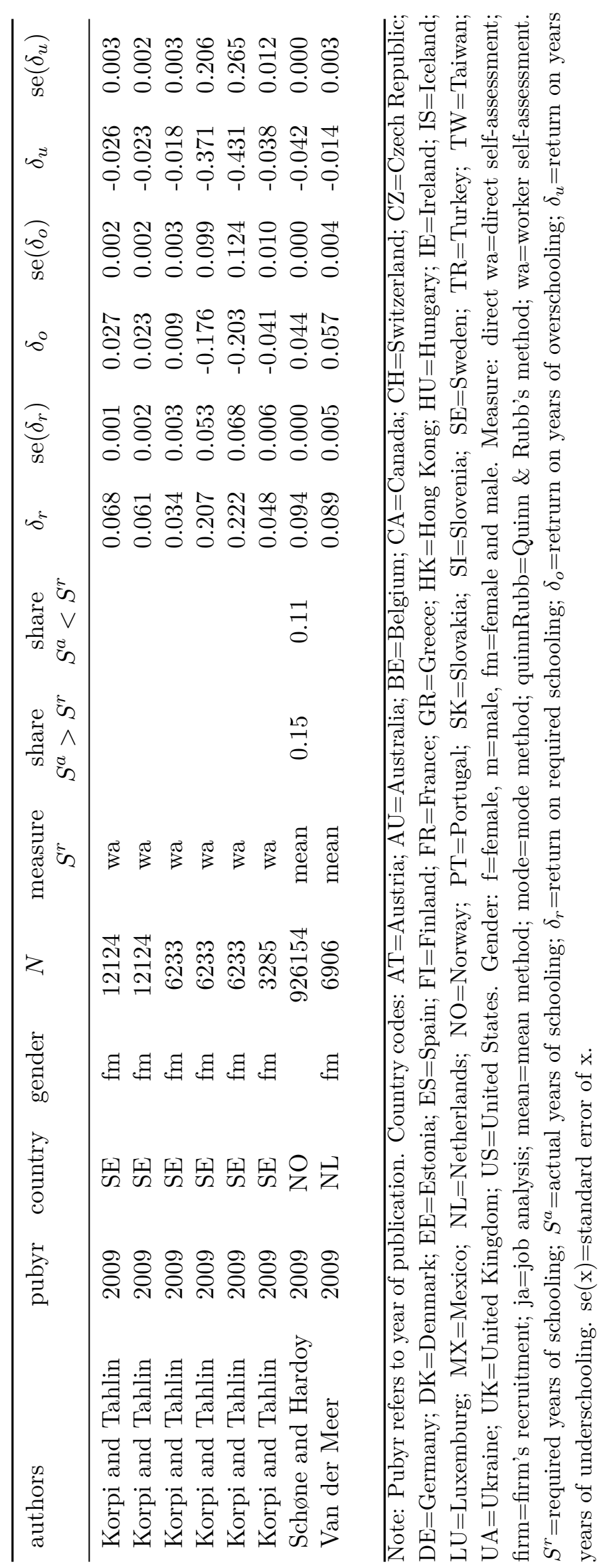

